\title{
فاعلية همكات هقترحة لتصحيح اختبارات اكتساب المفاهيم النحوية عند طلبة المرحلة المتوسطة
}

\section{The effectiveness of a proposed acquisition tests correction touchstones grammatical concepts when middle school students}

\section{Hussein Kareem Fouzan AL-sarray \\ وزارة التربية / المديرية العامة لتربية واسط / 11 مثام}

هسين كريم فوزاز السراي

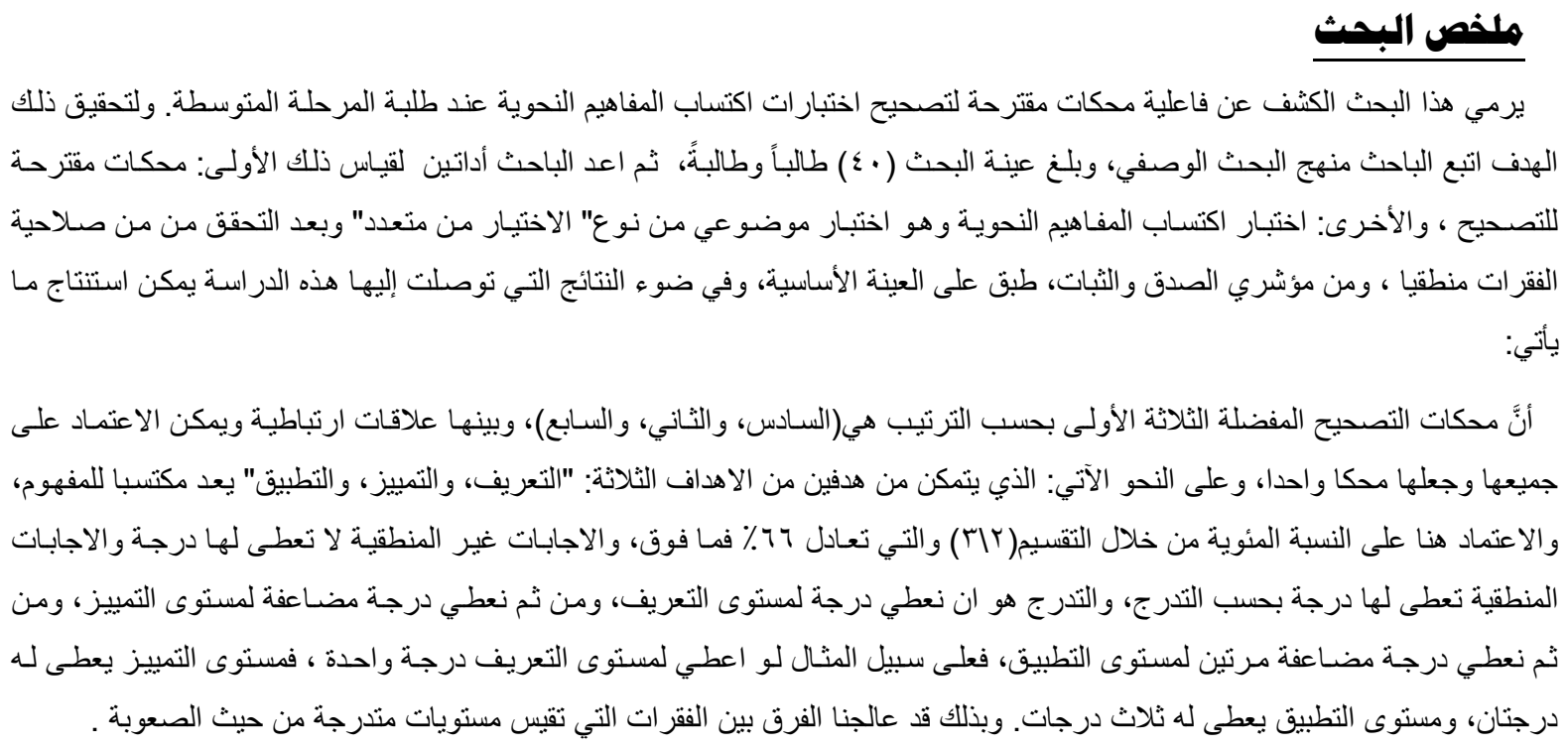

ABSTRACT

This research is aimed at revealing the effectiveness of a proposed acquisition tests correction touchstones grammatical concepts when middle school students. To achieve this goal follow Finder descriptive research approach, and reached a sample search (40) students, then the Finder tools to measure it first: touchstones for debugging, and other grammatical concepts and test is an objective test of type "multiple choice" after verifying the validity of logical paragraphs, and validity and reliability indices, applied to the core sample, in the light of the findings of this study can conclude what comes :

The first three touchstones favorite patch order (vi, II, VII), including relational ties and all reliable and made one test, as follows: who gets to three goals: "definition, and discrimination, and the app" is progressing of the concept, and rely here on the percentage by Division $(2 / 3)=66 \%$ and above, and illogical answers don't give her degree and logical answers given by degree gradient, And the gradient is to give a degree of visibility, and then give the double degree of discrimination, and then give the degree of doubling twice to the application tier, for example if I give one definition level, the level of discrimination gives him two degrees, and application level gives him three degrees. Thus he has treated the difference between paragraphs that measure the gradient levels in terms of difficulty. 
الفصل الأول: التعريف بالبحث

\section{Problem of studying مشكلة البحث: مش:}

من خلال اطلاع الباحث على البحوث التربوية التي تناولت في متغير اتها "اكتسـاب المفهوم" في المواد الدر اسـية جميعها، وبالخصـوص مفـاهيم مـو اد اللغـة العربيـة ، وكذللك مـن طريـق حضـور الباحث لبعض مناقتات طلبة الدراسات العليا التي كانت في عنو اناتهم مفردة "اكتساب المفهوم" شـاهد إن هنالك اختلافـا في عملية تصحيح اختبار اكتساب المفهوم و هذا ناتج من اعتماد الباحثين على محكات مختلفة فيما بينها لمعرفـة هل الطالب اكتسب المفهوم أم لا؟ وهذا الاختلاف يبين ان هناك اكثر من محك معتمد عند الباحثين في عملية تصحيح الاختبار ، وبالنتيجة فان ذلك يؤدي الى اختلاف في نتائج تحصيل الطلبة بـاختلاف تللك المحكات في عملية التصحيح ، ومن ثم سيؤدي منطقيا الى ضعف الاعتمـاد على نتائج البحوث المتخصصـة في اكتسـاب المفهوم كمتغير تابع في البحث العلمي؛ إذ إن الاعتماد على اكثر من محك في عمليـة التصحيح غير جائز ، لذا ينبغي الاعتمـاد على محك واحد فقط مفضل لدى الجميع وان يكون مقبول منطقيا حتى تتوحد عمليـة التصحيح لاختبار المفاهيم. لذا ارتأى الباحث الكثف عن محكات تصحيح مفضلة ومنطقيـة لاكتسـاب المفهوم ، ونتبلور مشكلة هذا البحث من خلال الاجابة عن السؤال الآتي: ما المحكات المفضلة والمتجانسة من بين تلك المحكات المقترحة لتصحيح اختبار اكتسـاب المفاهيم النحويـة عند طلبة المرحلة المتوسطة؟

\section{أهمية البحث والهاجة اليه: Importance of studying}

إن إعطاء صورة وصفية للإجابـة عن اسئلة هذا البحث تتيح المجال الى تحديد أهميته بمـا يضيفه الى المعرفة العلمية من الناحيتين النظرية والتطبيقية لذا بمكن تحديدها على النحو الآتي: المجال النظري: تبرز في هذا البحث بالآتي. ا ـ ندرة البحوث الدراسية العر اقية و العربية التي تتاولت موضوع محكّات تصحيح اكتساب المفاهيم النحوية. Y. هذه الدر اسـة سـتمهد السبيل لبحوث ودر اسـات أخرى في هذا المجـال الذي تتتـامى أهميتهـه في البحـث التربوي في المواد التعليمية الأخرى وكذلك استهداف فئات أخرى من العاملين في المؤسسات التربوية. المجال التطبيقي: تبرز في هذا البحث بالآتي.

ا ـ يعد معرفة محك تصحيح مفضل جو هري من بين عدة محكات امر ا مهمـا في الابتعـاد من عشو ائية الاختيار من بين المحكات في عملية تصحيح اختبار ات اكتساب المفهوم. r. تبرز أهمية الدراسة في معرفة التصحيح المفضل في تصحيح اختبـار ات اكتسـاب المفاهيم النحويـة التي تسهم في تقويم الطلبة ومعرفة ما تحقق فعلا من اكتسابهم لتلك المفاهيم. بـيعد التقويم من اهم العناصر الاساسية في بناء المنـاهج لذا ينبغي الاهتمـام في عملية اعداد الاختبـار ات 


\section{اهداف البحث: The Aim of Study}

يرمي هذا البحث تعرف"الكثف عن المحكات المفضلة من بين المحكات المقترحة لتصحيح اختبار ات اكتساب المفاهيم النحوية عند طلبة المرحلة المتوسطة".

\section{حدود البمث: Limits of The Study}

$$
\text { بتحدد هذا البحث بـ : - 2 }
$$

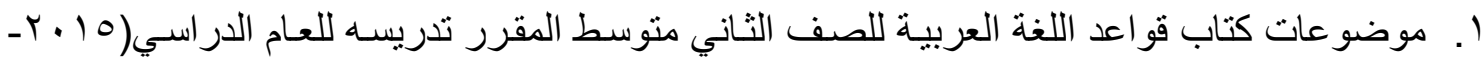

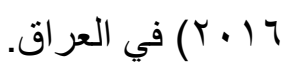

r. . طـلاب وطالبـات الصف الثاني متوسط في المدارس المتوسطة والثانويـة النهاريـة التابعـة للمديريـة العامة لتربية محافظة واسط.

\section{تصديد المطات:- Determine The terms}

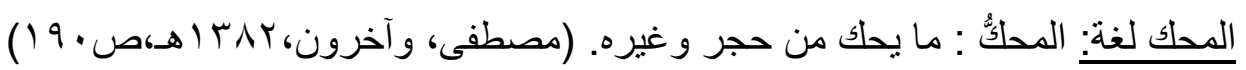
اصطلاحا: عرفه كل من:

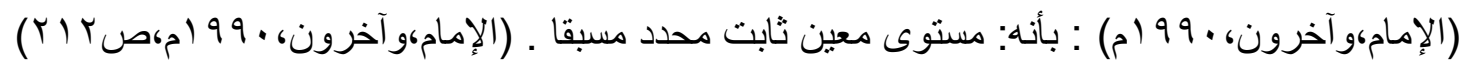

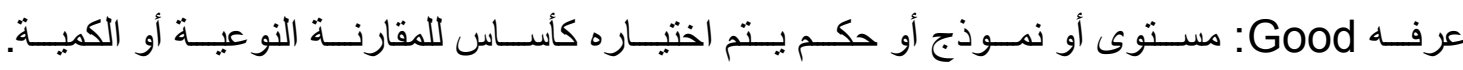
(Good,1973,P:153)

محكات التصـيح: لم يجد الباحث في الادبيات و الدراسـات السـابقة تعريف يجمـع بين مفهومي (المحكات و التصحيح) لذا ارتـأى الى أن يعرفهـ إجر ائيا: بأنه ادوات ووسـائل القياس التي تستخدم في تفسير درجـات

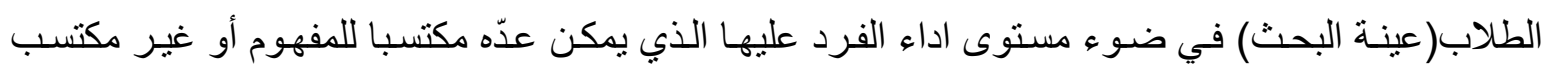

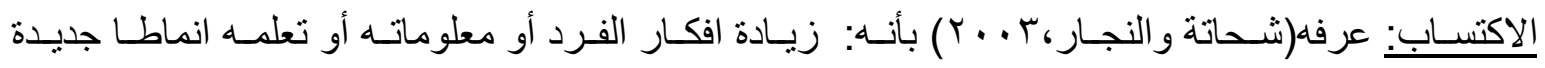

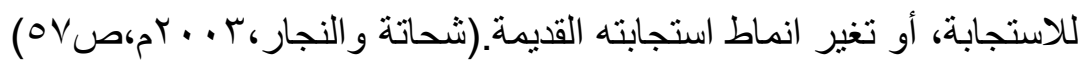

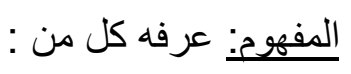

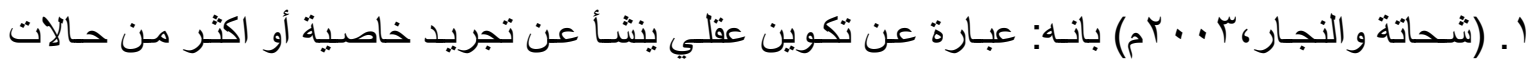

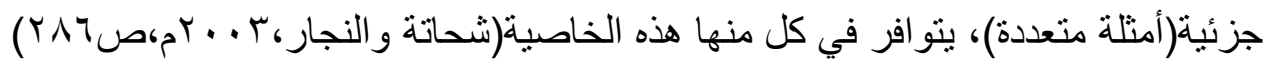
r. (الطيطي، ؛ . . r م): بانه: مجموعة من الصفات المميزة و المشتركة التي يلتقي عندها جميع العناصر في

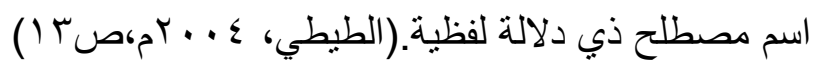
النحو: عرفه (عبد الحميد، 1؟ (هـ) بانـه: العلم بالقو اعد التي يعرف بها احكام أواخر الكلمات العربية في حال تركيبها من الاعر اب و البناء وما يتبع ذلك.(عبد الحميد، 1 أ (هـ، صك") 
المفاهيم النحوية: التعريف الاجر ائي للباحث بأنـه: مجموعة الصفات العامة التي تشترك فيها مجموعة من

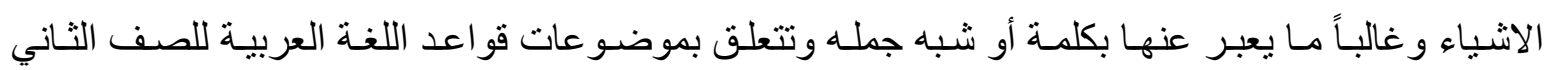

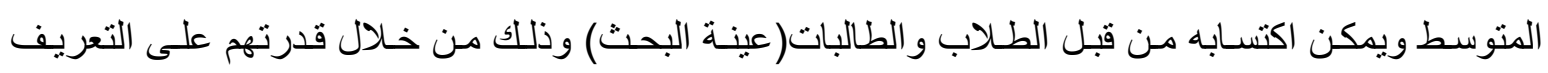
و التمييز و التطبيق.

المرحلة المتوسطة: جاء تعريفها ضمن نظام المدارس الثانويـة £^ه1 ا" يكون التعليم الثانوي على مرحلتين متتابعتين متوسطة و إعداديـة، مدة كل منهما ثنلاث سنوات ، وتعنى المرحلة المنوسطة باكتشاف قابليات

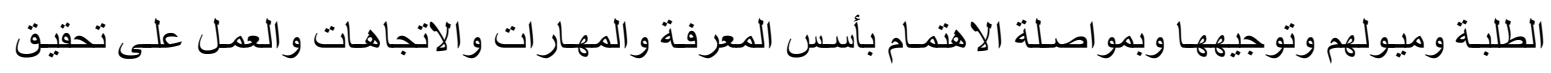

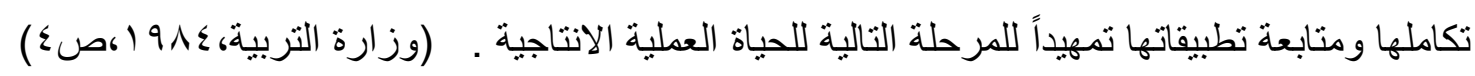

\section{الفصل الثاني: الإطار النظري}

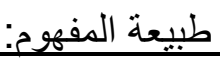

يدرك الانسان مفهوم الموجودات التي يحس بها مثل : محمد، هذا الكتاب، هذا القلم، هذه الوردة، بغداد، النجف. و اذا تأملها يجد كل واحد منها لا ينطبق على فرد آخر ولا يصدق الا على ذلك الموجود وحده ، وهذا هو المفهوم(الجزئي) ويصح تعريفه بانه" المفهوم الذي يمتتع صدقه على اكثر من واحد". ثم ان الانسـان اذ رأى جزئيات متعددة ، وقاس بعضها إلى بعض، فوجدها تشترك في صفة واحدة انتزع منها صورة مفهوم

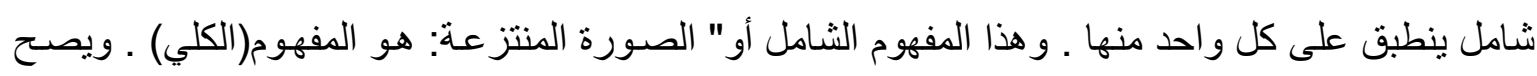
تعريفه بانه" المفهوم الذي لا يمتتع صدقه على اكثر من واحد" مثنل مفهوم: انسـان، حيوان، معدن، ابيض، تفاحة، حجر، عالم، جاهل، جالس في الدار، معترف بذنبه. و لا يجب ان تكون افراد الكلي موجودة فعلا: فقد يتصور العقل مفهومـا كليا صـالحا للانطباق على اكثر من واحد من دون ان ينتز عـه من جزئياته موجودة

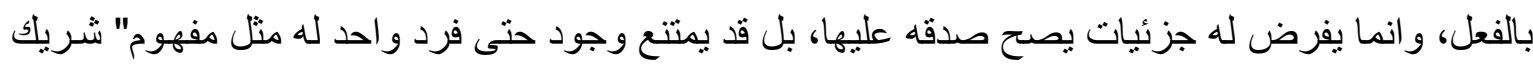
البارئ، ومفهوم: اجتماع النقيضين" .و لا يضر ذللك في كليته. وقد لا يوجد لله الا فرد واحد ويمتنع وجود غيره، مثل مفهوم" واجب الوجود" ؛ لقيام البرهان على ذللك، ولكن العقل لا يمنع من فرض افر اد لو لو وجدت

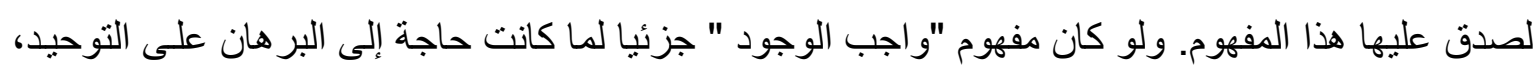
وكفى نفس تصور مفهومه لنفي وقوع الثركة فيه. و عليه فهذا الانحصار في فرد واحد انما جاء من قبل امر هر هري خارج عن نفس المفهوم. الا ان نفس المفهوم يمتتع صدقه على افراد كثيرة. اذن ؛ بمقتضى هذا البيان لا بـ من اضـافة قيد "ولو بـالفرض" في تعرفه الجزئي والكلي، فالجزئي: "مفهوم يمتنع صدقه على كثير ولو

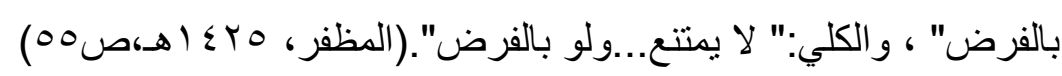

فالمفهوم :هو "نفس المعنى بما هو، أي نفس الصورة الذهنية المنتزعة من حقائق الاشياء. و المصداق:

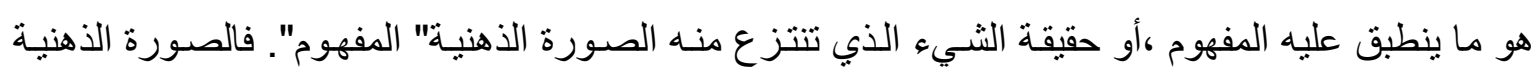
لمسـى "محمد" مفهوم جزئسي، والثـخص الخـارجي الحقيقي مصداقه. والصـورة الذهنيـة لمعنىى" الحيوان"

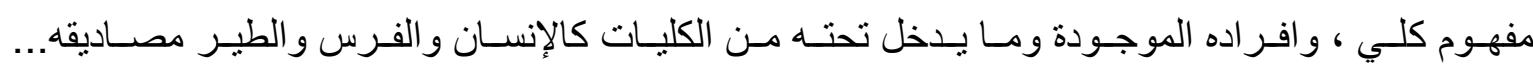

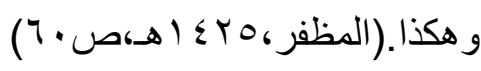


اننا نبني عالمنا بالمفـاهيم ، أنها موجودة بكل الانواع وبعضهها اكثر اهمية من البعض الاخر، وبينمـا

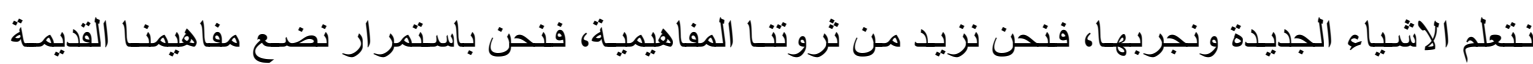
موضع الاستعمال ، ومع مرور الزمن وباستمر ار نوسع هذه المفاهيم، ونكتسب مفاهيم جديدة متعلقة بالقديمة

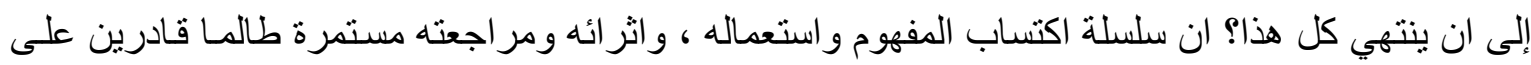
التفكير ـ وبالإضافة إلى قدرة المفاهيم على مسـاعدتنا في تلبيـة احتياجاتتـا اليوميـة، فعالمنـا العقلي مكون من فن ملايين البنى المعرفيـة (العقلية) وكل هذه البنى، تتطلب نوعـا منفصـلا في شبكتنا المعرفية لأن استرجاع المعلومات سوف يكون صعبا كليا اذا لم تكن منظمـة ، وتسمح لنـا المفاهيم بتنظيم وتخزين كمية كبيرة من

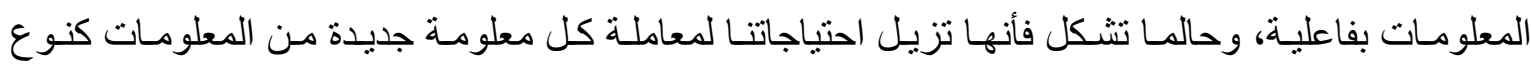

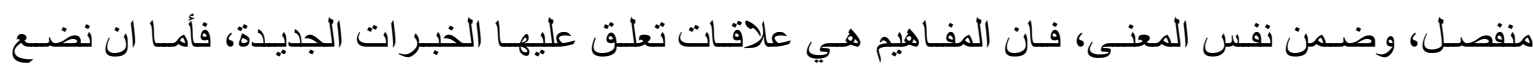
المعلومـات على علاقة غير ملائمسة، أو أن نوجد لها واحدة جديدة ، وباختصـار ، فـان المفاهيم تنظم بنيتنا

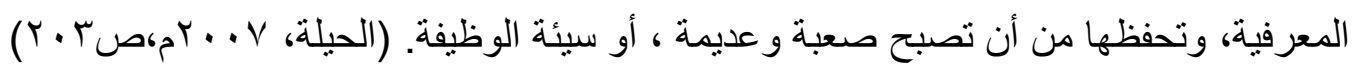

\section{المفاهيم النحوية وانواعها:}

كلمة التفاحة دالة على شيء له مفهوم مشتمل على خصاص الثمرة المحسوسة من حيث الثكل و اللون و الطعم و الر ائحة، و هذا يختلف عنـه عندما تكون التفاحـة مفهومـا مجردا كالمبتدأ في الجملة الآتيـة: "التفاحـة طعمها لذيذ"، فالمفهوم هنا مبتدأ وليس التفاحة الدالة على مفهومها المحسوس، فقد يكون موقع التفاحة خبزا

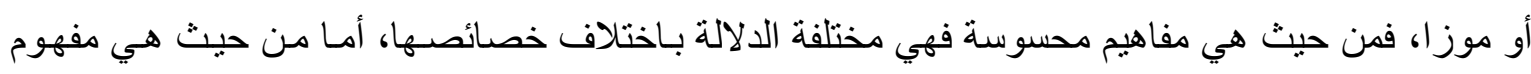

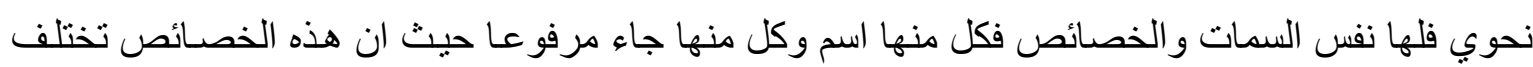

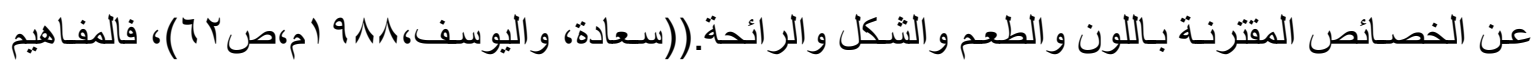
النحوية من النوع المجرد التي لا يمكن ادر اكها عن طريـق الحواس، فـالرمز أو الكلمة ليس المفهوم ذاتـه، ولكن المفهوم هو مضمون هذه الكلمة ، ودلالة هذا الرمز في ذهن المتعلم، مثلا: كلمة المبتدأ ليست مفهومـا ،

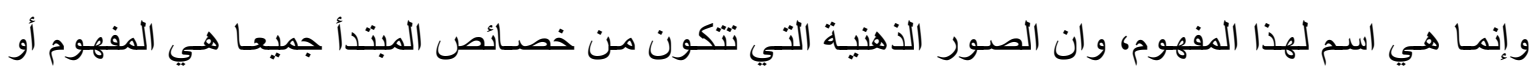

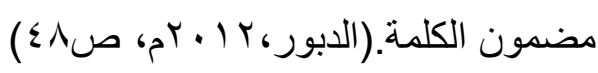
وقد صنفها (زيتون، و 9 (1) على ستة اقسام هي: أ. المفاهيم الاجر ائية: وهي المفاهيم المتعلقة بالإجر اءات التي يؤديها الفرد مثل: الحركة والنوم. ب. المفاهيم التصنيفية: وهي المفاهيم التي تقع ضـمن صنف معين أو ضـمن مجموعـة معينة، مثل الفعل الماضي يقع ضمن الأفعال. ج. المفـاهيم الربطيـة: وهـي المفـاهيم التـي يـتم فيهـا دمـج فكرنين أو شـيئين في الاقـل، مثنل: الصـفة تتبع الموصوف في الاعراب و التذكير والتأنيث و الافر اد و التنتية والجمع. 
د. المفاهيم العلائقية: وتمثل العلاقة بين شيء وآخر وبين مفهومين أو اكثر، مثل: تدخل ان واخواتها على المبتدأ و الخبر فتنصب الاول اسما لها وترفع الثاني خبر الها، فهذا المفهوم يتضمن العلاقة بين عدة مفاهيم " المبتدأ و الخبر و الرفع و النصب". هـ. مفاهيم فصل: وتكون عكس مفـاهيم الربط؛ إذ تُنـى على اسـاس عزل الافكار أو الاشياء أو الاحداث، ويستعل فيها حرف العطف(أو) الذي يفيد معنى الفصل، مثل الظرف يثير أما إلى زمان أو مكان. و. المفاهيم الوجدانية: و هي المفاهيم التي تقع ضمن المجال العاطفي الوجداني الذي لله علاقة بـالميول و القيم

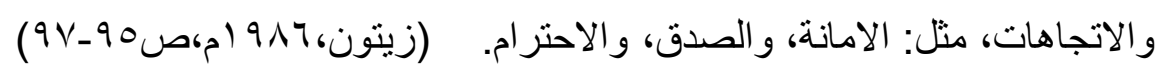
هكونات المههوم : يتكون المفهوم من العناصر الاتية : ( ) اسم المفهوم ، ويثير إلى الصنف الذي ينتمي اليه المفهوم . r) الأمثلة المنتمية إلى المفهوم ( الإيجابية ) ، والأمثلة غير المنتمية اليه • السلبية ) . ب)الخصائص أو السمات المميزة للمفهوم وغير المميزة لـه ، وتمثنل المظـاهر العامـة التي تضـع الأمثلة في فئة معينة أو مجمو عة محدة ولكل مفهوم خصائص مميزة و أخرى غير مميزة . ع) قاعدة المفهوم أو القانون ، وهي العبارة التي تحدد المفهوم ، مثنل الفاعل اسم مرفوع يدل على من فعل

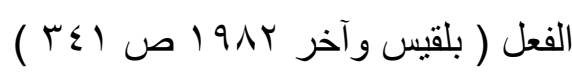
ويبدو ان المفهوم يمكن تكوينـه مـن طريـق توظيف الحو اس الخمسـة والخبرات و المو اقف السـابقة ، وتفعيلها مع البيئة، فينتج عن ذلك تكوين صورة ذهنية بناء على ادر اكه لمجموعة مشتركة من الصفات، ومن

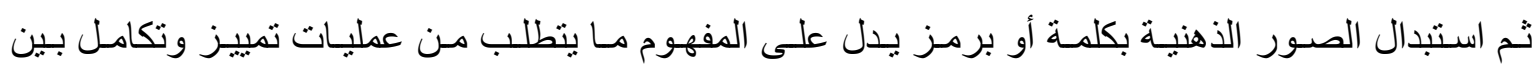
الخبرات، وبذلك بتم تشكيل المفهوم لدى الافر اد.

خصائص المفهوم:

هناك ثلاثة اتجاهات تحدد خصائص المفهوم ، هي على ما يأتي :

الاتجاه الأول : يقصد بالخصائص المشتركة عناصر منطابقة بين المثيرات التي يجمعها المفهوم ، مثال على ذللك مفهوم ( الأسماء الخمسة ) فمن الممكن ان تختلف هذه إماء من حيث هي اسماء بذاتها ، الا ان جميعها تشترك وتتطابق في وجود عدد معين من الصفات المشتركة معا من حيث رفعها ، ونصبها ، وجر ها . الاتجاه الثاني : يحدد هذا الاتجاه الخصائص المشتركة بانها علاقات جزئية بين الأشياء وليس تطابقا ، مثنال

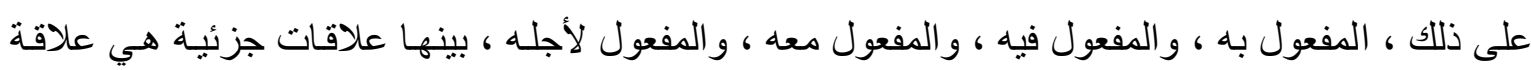
منصوبات الأسماء في كل منها . 
الاتجاه الثالث : يرى هذا الاتجاه ان الخصـائص المشتركة هي المعنى المتوسط، مثنال على ذلك، النواستخ،

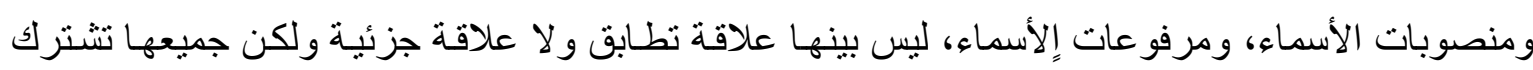

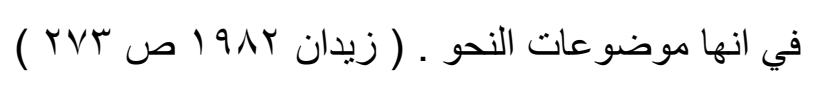

ابعاد قياس المفهوم:

هنـاك عدة ابعـاد لقيـاس مدى اتقان الطلبـة للمفهوم و لا بـد مـن طرح حعدد مـن الاسئلة و ايضـا بعض خصائص المواد التعليمية: الفقرة( (): تقيس قدرة الطالب على اختيار (مثالا) على المفهوم ، فيما لو اعطي اسم المفهوم. الفقرة(r): تقيس قدرة الطالب على اختيار (لا مثالا) على المفهوم ، فيما لو اعطي اسم المفهوم. الفقرة(r): تقيس قدرة الطالب على تحديد اسم المفهوم ، فيما لو اعطي (مثالا) على المفهوم. الفقرة(§): تقيس قدرة الطالب على اختيار الخصائص المعيارية للمفهوم ، فيما لو اعطي اسم المفهوم. الفقرة(0): تقيس قدرة الطالب على اختيار الخصائص اللامعيارية ، فيما لو اعطي اسم المفهوم. الفقرة( ا): تقيس قدرة الطالب على اختيار التعريف الصحيح للمفهوم ، فيما لو اعطي اسم المفهوم. الفقرة(V): تقيس قدرة الطالب على اختيار مفهوم أوسع مرتبط بشكل كبير بـالمفهوم المحدد ، فيمـا لو اعطي

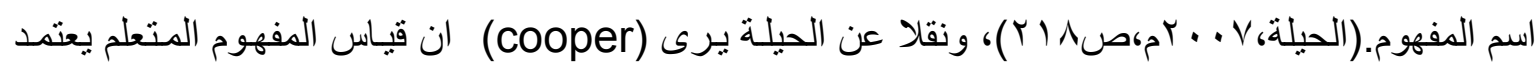
على الابعاد الاتية: ا-تحديد أو تعريف الخصائص المعيارية للمفهوم. r- بـ تمييز الامثلة من اللاأمثلة. r- تعريف أو تحديد قاعدة المفهوم. ع- القدرة على ربط المفهوم بمفاهيم أخرى. 0ـ استخدام المفهوم بطريقة جديدة أو غير عادية.

واعتمادا على اهميـة المفهوم ، فأن مدى الاتقان يمكن أن يتم تقيمها، من خـلال بعد واحد ، أو من خلال هذه الابعـاد ـ وبالنسبة للكثير من النشاطات التعليمية السـهلة سوف يكون كافيـا لذلك ، وفي مو اقف

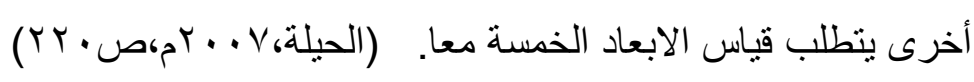
ويرى الباحث ان الخصائص المعيارية وغير المعيارية للمفهوم وكذلك عملية الربط بمفاهيم أخرى ذات

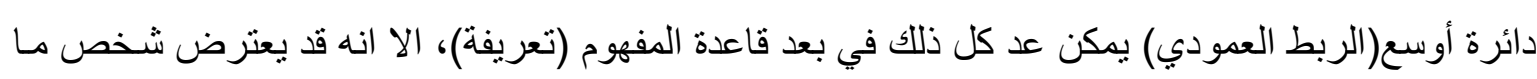

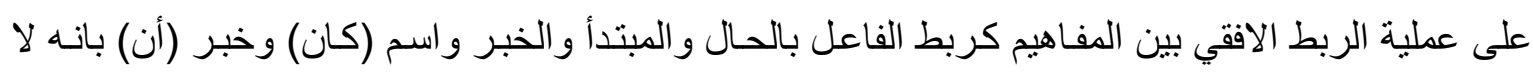
يعد ضمن قاعدة المفهوم، فنقول: أن وجود الفصل الذي هو من ذاتيات المعرَّف و الذي بدوره يمنع دخول دئي

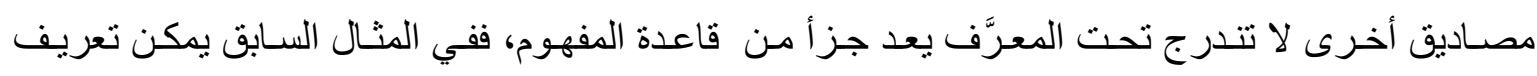


الفاعل: بأنه اسم مرفوع مسبوق بفعل تام، فمن خـلال تلك القاعدة نستتنج أن هناك ثلاثنة خصـائص معياريـة لمفهوم الفاعل و هي: (الاسم، و المرفوع، و المسبوق بفعل تام) وأن وجود الخصيصة المعياريـة الثالثة للمفهوم و هي( مسبوق بفعل تام) تعد الحد الفاصل لمنع دخول مصاديق أخرى لا تندرج تحت المعرَّف(الفاعل ) مثل ونل المبندأ الذي ايضا اسم ومرفوع الا أنه غير مسبوق بفعل تام نام .

\section{المحكات والمعايير في القياس والتقويم:}

المعاييز:

لغويا المعيار هو مقياس ، و المعايير في العلوم التربوية هي موازين مستوى اداء مجموعة في اختبار مـا

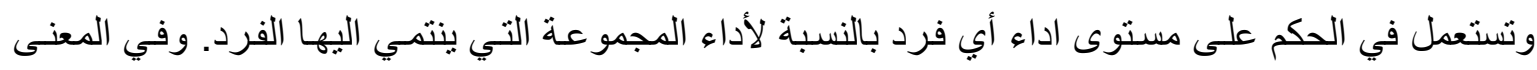

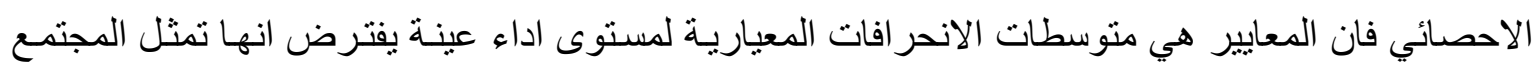

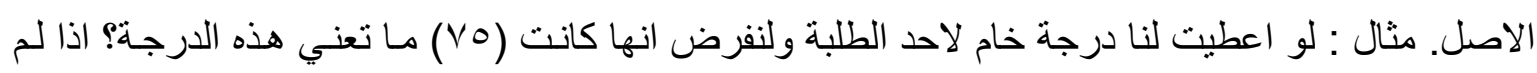

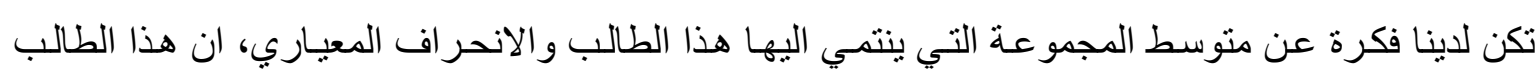
يقارب أو يتفوق أو يتخلف عن المجموعة ؛ لأنه فوق أو تحت المتوسط، ولكننا لا ندري بكم هو يختلف عن هن هن

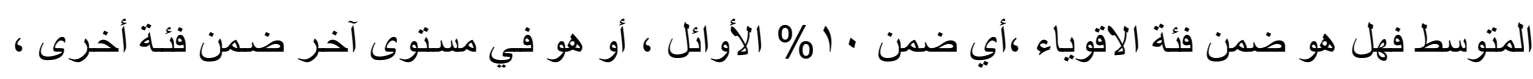

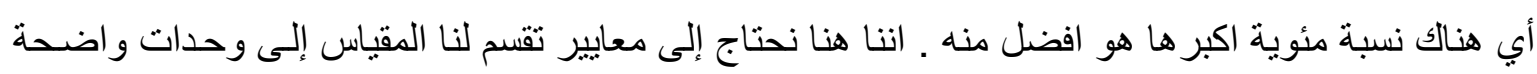

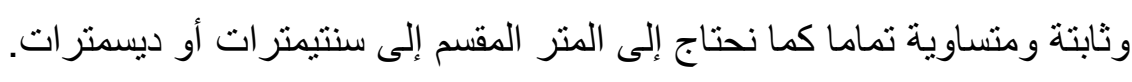
وقد نعد مقياسا لقياس التحصيل يقسم مستويات اداء الطلبة بعد القياس على مئة قسم وتسمى المعايير المئينية، أو نقسم المستويات على ستة اقسام منسـاوية وتسمى المعـيير الزائيـة، أو على خمسـة أو على تسعة تماما كما نقسم المسطرة إلى وحدات قياس تارة الاتج، وتارة أخرى السنتمتر ، وتارة الملمتر ، وهذا يقودنا إلى لى

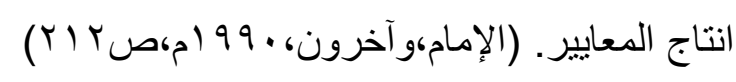

\section{أنواع المعايير:}

هناك انواع عديدة ومختلفة من المعايير التي نحاول ان نقيس بها مستويات اداء الطلبة ويمكن تصنيفها على نوعين اساسبين هي: ا ـ المعايير الاحصائية (المستعرضة): وهي المعايير التي تقسم المستويات أو الفروق الفرديـة على وحدات قياسية منساوية وثابتة من المئينات والمعيار السداسي(الزائي) أو المعيار التساعي.. ז- المعايير الوصفية (الطويلة):وهي المعايير التي توضـع تبعـا لمتغيرات مثل المعايير العمريـة والمعايير الصفية أو تبعا للجنس.

وفي العلوم التربويـة والنفسية نحتاج إلى جميع هذه المعايير في استعمالات مختلفة فأننـا مثنلا نحتـاج إلى

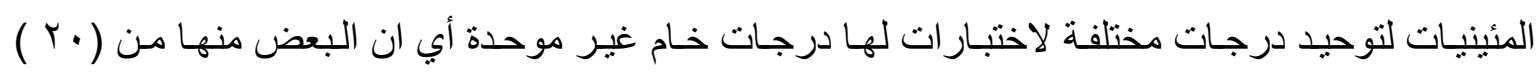

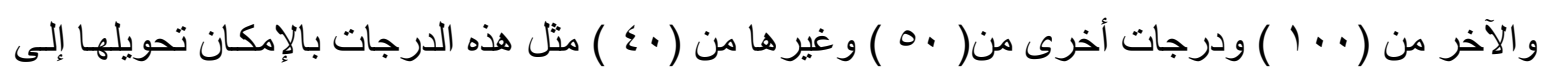
وحدات قياسية موحدة مثل المئينات أو الدرجات المعيارية أو غير ها. 
ونحتاج ايضا إلى المعايير الوصفية لمعرفة مستويات اداء كل صف أو عمر في مـادة معينة لمجتمع مـا أو للبلد ككل وقد نحتاجها لمعرفة مستويات عامة ويحدث هذا اذا اردنا بناء اختبار ات وطنية أو تطبيق اختبار ات أخرى معربـة. وفي قياس الذكاء والقدرات العاليـة نحتـاج إلى معايير تبعـا للجنس كأن نعرف ان ان معايير

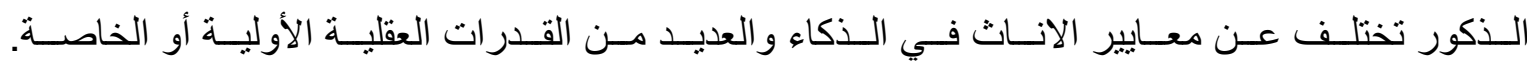

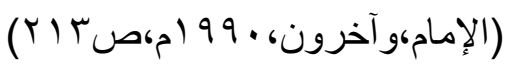

المكات:

المحكـات لهـا ثــة انو اع عديدة ، فقد تكون مجموعـة احكام المختصين، فر أب المهندسين مـن ذوي الخبرة الميدانية هي المحك لقياس القدرات الهندية، وقد تكون المو اظبة وعدم الغياب أو نسبة الانتاج كمحك لكفـاءة العاملـ، أو رأي الطلبـة في استاذهم كمحلك لكفـاءة الاستاذ التدريسية في الجامعـة، واهـ المحكـات التربوية التي تستعمل اليوم لتقويم كفاءة أو تحصيل الطالب هي الاهداف التربويـة أي إلى أي مدى استطاع اتقان أو اكتساب اهداف تربوية معينة بغض النظر عن تسلسله أو رتبته بين اقرانه . لقد اكتثف العديد من المختصين بالتقويم والقياس بأن قياس الفروق الفردية بين الطلبة بوسـاطة المعايير لم يكن دائمـا كافيا لمعرفة المستوى النوعي لتحصبل الطالب فيكون الطالب الأول أو الثالث أو الوسط لا يوضح مدى اتقان الطلبة اهداف تحصيلية أو تربوية معينة و لا يكثف عن الصعوبات التعليمية للطلبة فكان التوسـع في استعمال الاهداف التربويـة بأنو اعهـا كمحكـات لتقويم الطلبـة ـ وهذا مـا اعطى اهميـة لمعرفـة الارتباط بين درجات الطلبة و المحكات التربويـة. ان الاتجـاه الأول الذي يطلق عليه معياري المرجع كان

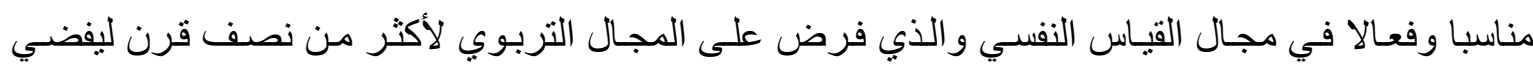
تدريجيا إلى نوع واتجاه جديد هو القياس المحكي المرجع و إلى ظهور القياس التربوي كمجال تخصص جديد

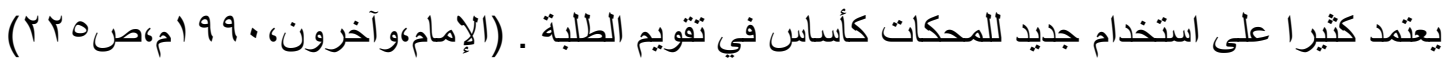

\section{همكات هقترحة لتصميح اختبار المفاهيم النحوية:}

من المحكات المقترحة التي اعدها الباحث هو النظر إلى اكتسـاب المفاهيم على انها عملية تحصيل اي ان معيار التصحيح في اختبار ات اكتساب المفاهيم لا يختلف عن اختبار ات التحصيل، وكذلك النظر إلى كون المتعلم قد اكتسب المفهوم من خـلال الاهداف الثلاثة وهي: "التعريف، والتمييز، و التطبيق" فالذي يحصل على هدفين من الاهداف الثثلاثـة فانسه قد اكتسب المفهوم وقد اعتمدوا هنـا على النسبة المئويـة من خـلال

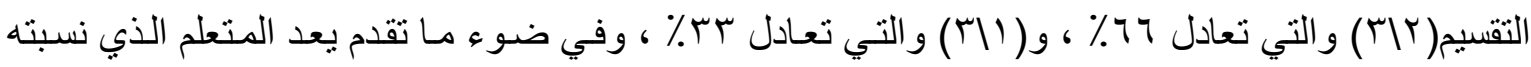

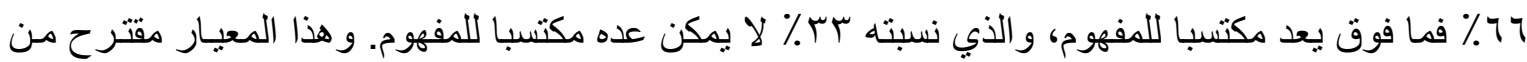
قبل الباحث و الذي مفاده هو "ان الذي يكتسب المفهوم عليه ان يعرف ويميّز ويطبق ذلك المفهوم فلا يمكن عد ذلك المتعلم الذي يعرف ويميّز مكتسبا للمفهوم. وهذا معيار آخر مقترح من الباحث الذي مفاده هو "ان الادبيات و الخبر اء يرون ان المفهوم تدريجي في خطوات اكتسابه فالذي يميز المفهوم لا بد لـه انه قد عرّفهـ ، والذي يطبق المفهوم لا بد له انه قد ميزه و عرفه قبل ذلك. لذا يكون المقترح ان المستوى الاعلى هو عملية

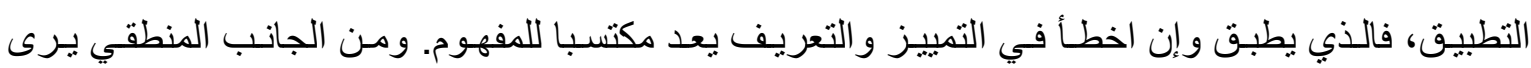


الباحث انه ينبغي متابعة المستويات الثناثة للمفهوم الواحد فالمتعلم الذي يميز المفهوم ويخطئ في تعريفه، أو الذي يطبق المفهوم ويخطئ في تمييزه، أو الذي يعرف المفهوم ويطبقه ولا يستطيع تمييزه، أو الذب يطبق المفهوم ويخطأ في تمييزه وتعريفه، أو الذي بطبق المفهوم ويميزه ويخطأ في تعريفه. أي انهه يمكن توضيح الكلام السابق بجعل رموز لتلك الاهداف ورسم مخطط لها وعلى النحو الآتي :
التطبيق(x)
التمبيز(ل)

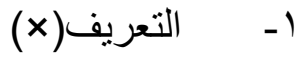
التطبيق(V)
التمبيز(ل)
r- التعريف(x)
التطبيق(ل)
التمييز(x)
r- التعريف(x)
التطبيق(ل)
التمييز(x)
ع- التعريف(ل)
التطبيق(x)
التمبيز(ل)
0- التعريف(ل)
التطبيق(x)
التمبيز (x)
ד- التعريف(ل)
التطبيق(ل)
التمبيز(ل)

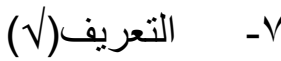
التطبيق(×)
التمييز(x)
1- التعريف(x)

ومن خلال الثكل السـابق نسـأل أيهما صـحيح وممكن منطقيـا أن تكون الاجابـة بحسب التدرج في اكتسـاب المفهوم. لذا نرى من تلك الاجابات المفترضة الثمانية أن المنطقي منها من حيث التدرج فقط هي(0، 7، V،

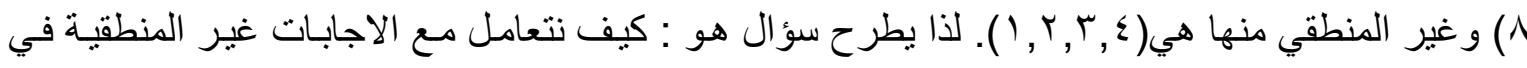
عملية التصحيح؟ ويمكن الجواب عن السؤال بالآتي: الاجابات غير المنطقية لا تعطى لها درجة وله والاجابات المنطقية تعطى لها درجة بحسب التدرج.

و هنالك مقترح جديد هو اذا اردنـا ان نتماشسى مـع المعيار الأول ونقول لا نريـ ان نبخس حق احد في الاجابة ونتعامل مع اختبار المفهوم كتعاملنـا مـع اختبار التحصيل، الا انتـا نريد أن نفرق بين ذلك؛ لأن من عيوب ذلك ان هذا يؤدي إلى اجابـات غير منطقية مع اخذ الدرجات عليها فعلى سبيل المثنال لو ان هنالك

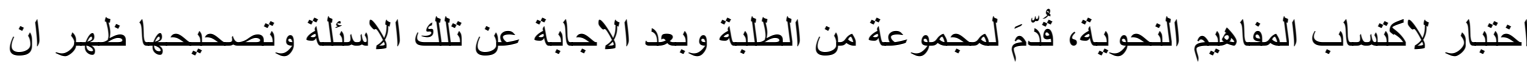
الطالب (أ) قد اجـاب بصـورة صـحيحة على مسـتوى التعريف ، وقد أخطأ في مسـتوى التمبيز ومستوى

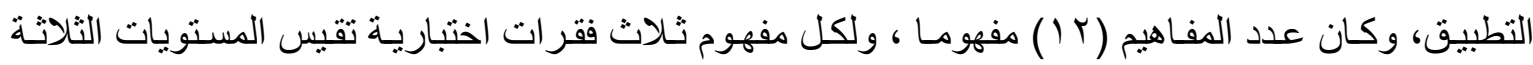
للمفهوم ، و هي "تعريف وتمييز وتطبيق"، وبذللك يصبح عدد الفقرات الكلي "جr" فقرة ، و هذا يعني أن وهن الطالب (أ) عندما أجاب إجابة صحيحة على جميع فقرات مستوى التعريف فقط، وهي (Y I ) فقرة ، لذا فانهـ

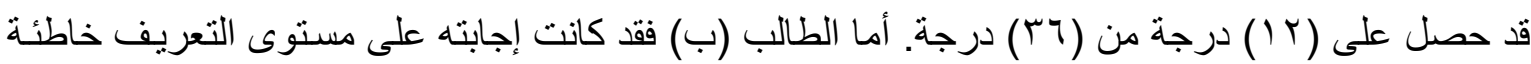
في جميع المفاهيم ،الا انه قد اجاب على مستوى التمييز بصورة صحيحة، فهذا الطالب سيحصل على نفس درجة الطالب (أ) و هي( r I ) درجة ، و هكذا دو اليك. فلو رجعنا إلى الافتر اضـات لنرى كيفية حصول الطلبة

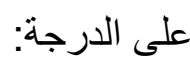
التطبيق(×
التمبيز)

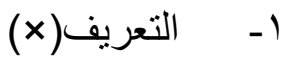

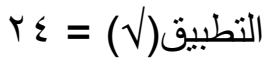
التمييز(ل)
r- التعريف(×) 

التطبيق(V)
التمبيز)(x)

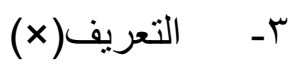

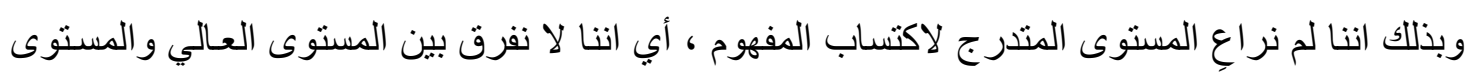

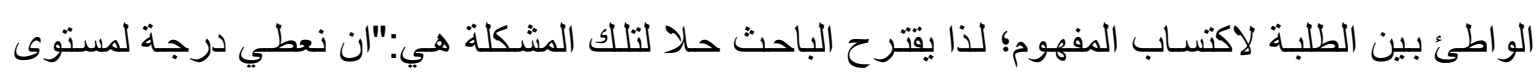

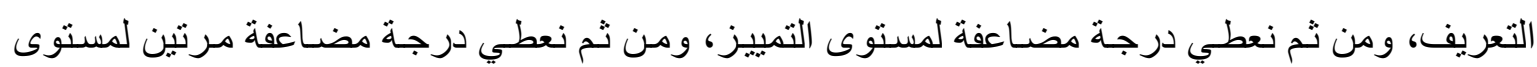
التطبيق، فعلى سبيل المثال لو اعطي لمستوى التعريف درجة واحدة ، فمستوى التمييز يعطى له درجتان، ومستوى التطبيق يعطى له ثلاث درجات. وبذلك قد عالجنا الفرق بين الفقرات التي تقيس مستويات متدرجة

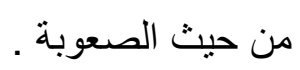

ان هذا البحث سبطبق على نتائج اختبار يعده الباحث لاكتسـاب المفاهيم النحويـة، وبعد ذلك نطبق عليه

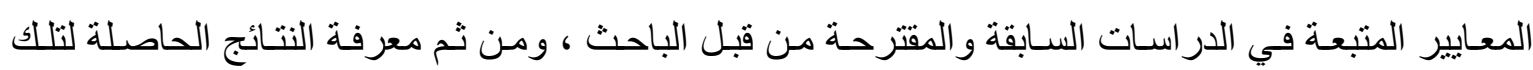

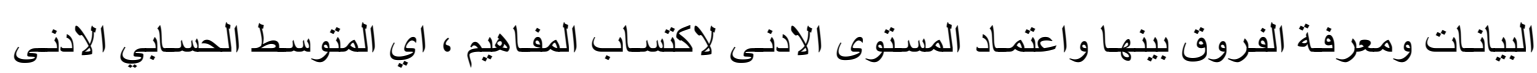

للعينة"

\section{الفصل الثالث: الدراسات السابق \\ ا. در اسة العتيبي و غالب 997 ام:}

اجريت هذه الدر اسة في مصر ، ورمت تعرف"معـيير مقترحة للاعتمـاد الاكاديمي و المهني لبر امج

اعداد المعلمين في الجامعات العربية"، و اعنمد الباحثان على المنهج الوصفي التحليلي اسفرت الدراسئة

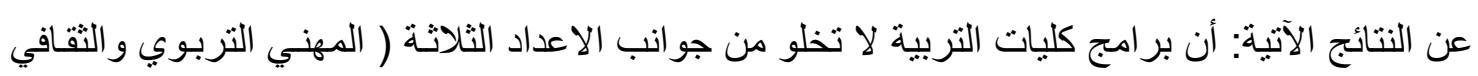
و التخصصـي) إلا أن التباين يظهر في تصميم هذه البر امج و المتطلبـات التي تكون عناصـر ها ، وقد

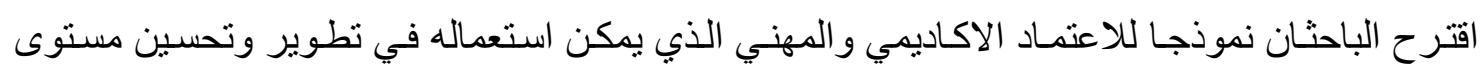
بـر امج اعداد المعلمين في الجامعـات العربيـة وهذه المعـيير تتتـاول سـت فئـات تتمثنل في ( الادارة،

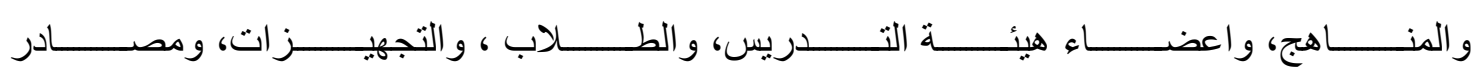

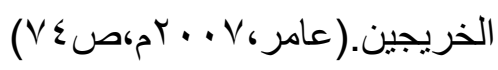

Y. در اسة عبد الرحمن وحسن ع . . rم: اجريت هذه الدراسـة في مصر، ورمت تعرف معايير الاداء المهني للطالب المعلم بكليات التربية في ضو ع مفهوم الجودة والاعتمـاد التربوي. استخدم الباحثنان ثناث ادوات هي: بطاقة ملاحظة الاداء المهني للطالب المعلم، واستبانة معتقدات الطالب المعلم، واستبانة ثقافة

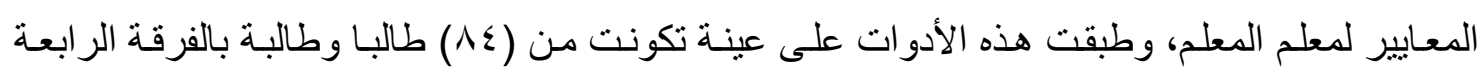
تخصص علوم ورياضيات ، و( • (T) عضوا من اعضاء هيئة التدريس بكلية التربية بطنطا، وقد اسفرت

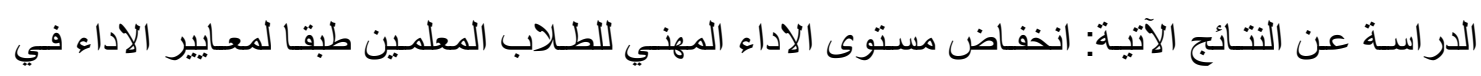

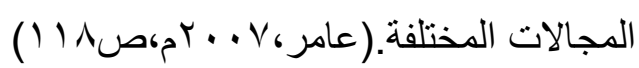

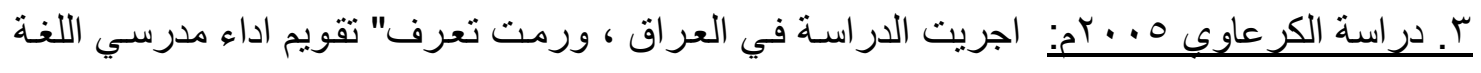

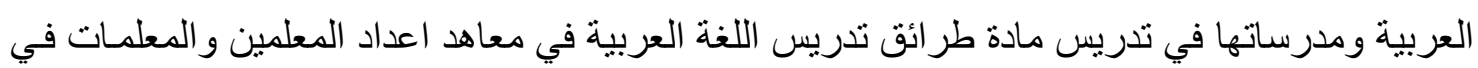


ضو كء كفاياتهم التعليمية" وذلك من خـلال تحديد الكفايـات التدريسية اللازمـة لأداء مدرسي اللغنة العربيـة ومدرسـاتها في تدريس مـادة طر ائق تدريس اللغـة العربيـة، وتحديد مستوى اداء مدرسي اللغـة العربيـة

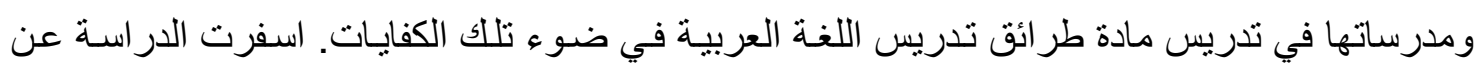

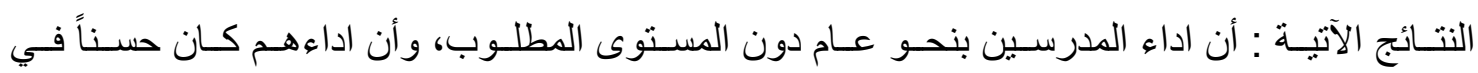
المجالين:" كفايات العلاقات الانسانية وادارة الصف، وكفايات استثارة الدافعية"، اما اداؤهم في المجالات الخمسة وهي (التقويم، استخدام الوسـائل التعليمية، التخطيط والاعداد للدرس، الاهداف التربويـة، تنفيذ

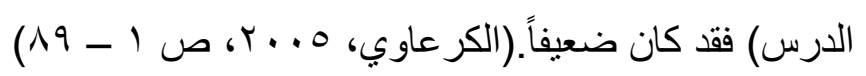

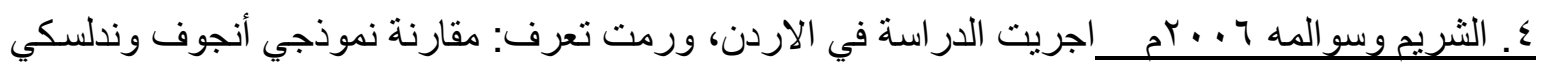
لتقدير درجة القطع لاختبار محكي المرجع في الرياضيات، وذلك من خلال وجود مؤشر ات عن صعوبة وكنة الفقرات أو عدم وجودها. وتكونت عينة الدراسة من ثمانين محكماً ومحكمة. وقد تم تقسيم المحكمين بطريقة

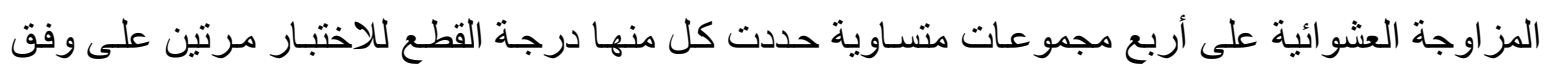

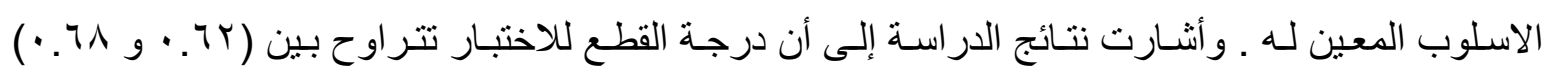

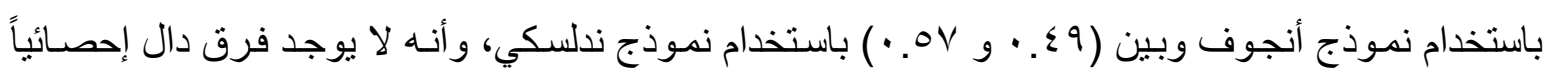

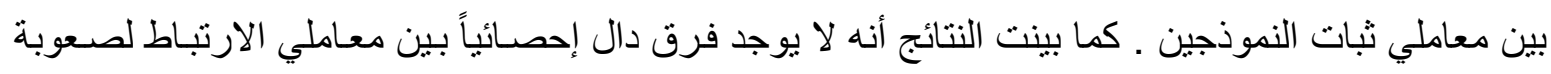

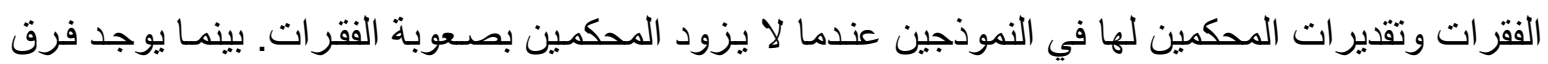

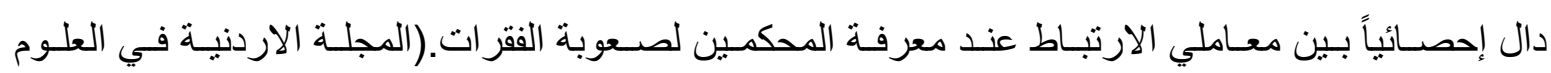

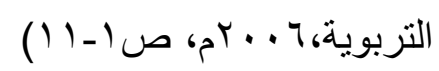

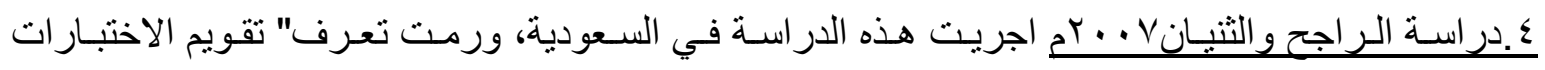

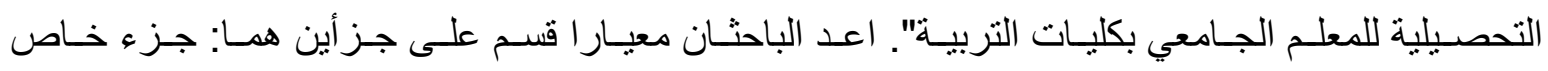
بالمو اصفات الفنية للاختبار ، وجزء خاص بمو اصفات نوع الاسئلة، وهي: الاسئلة الموضوعية التي تضم

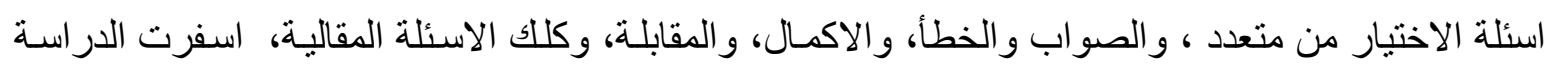
عن النتائج الآتية: ان المواصفات الفنية التي تم تحديدها في معيار وضع الاختبار ات التحصيلية متوافرة، وان الاختبار ات الموضـوعية لم تكن شـائعة في صياغة الاختبار ات التحصيلية للمعلم الجـامعي وقد جـاء توافر

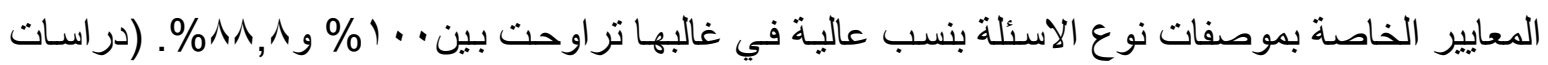

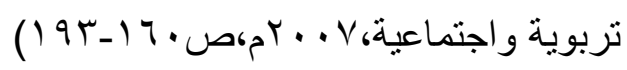

ع ـدر اسة داخل 1 ـ ـ بح اجريت الدراسة في العراق ، ورمت تعرف" محكات تصحيح التعبير الثفهي عند

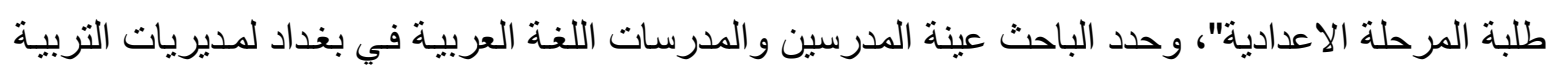
الستة، واستعمل الباحث المنهج الوصفي المسحي، فكانت عينة بحثنه (YOV)، واعد الباحث اداة لبحثنه من

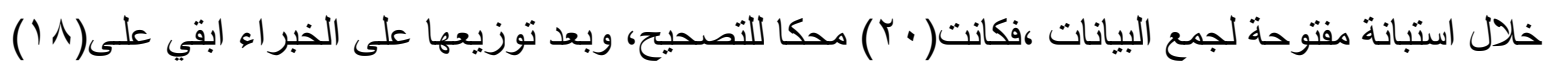
محكا، وباستعمال الوسط المرجح والوزن المئوي اظهرت النتائج الابقاء على(10 1 ) محكا للتصحيح، وابعـاد (ץ) محكات، وكانت ابرز النتائج حصول معيار "صحة مخـارج الاصوات" على الترتيب الأول، ومن ثم 
معيار "التعبير بالكلام الفصيح و الابتعاد من العامية ما أمكن" على الترتيب الثاني، ومن ثم معيار "جهوريـة

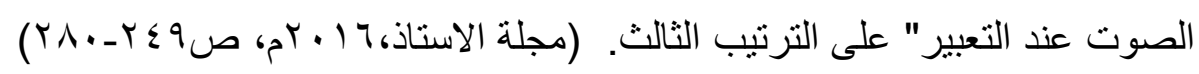
الفصل الرابع :منهجية البحث واجر اءاته

\section{هنهجية البحث واجراءاته}

يضم هذا الفصل تحديد منهج البحث و الإجر اءات الكفيلة بتحقيق أهدافه بدءاً من تحديد مجتهع البحث و اختيار العينة وإعداد أدوات البحث ،واختيار الأدوات و المعالجات الإحصـائية المستعملة في تحليل البيانات و على النحو الآتي :أولاً - منهجية البحث

اتبع الباحثث منهج البحث الوصفي؛ إذ يُعدُّ من المنـاهج التي تسعى إلى تحديد الوضـع الحـالي للظـاهرة

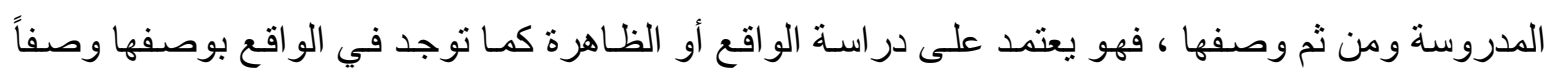
دقيقاً.

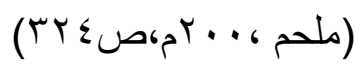

ثنانياً- مجتمع البحث

إنَّ تحديد المجتمع عملية أساسية ينبغي الاهتمام بها و على الباحث أن يحدد مجتمع بحثه تحديداً دقيقاً ؛إذ

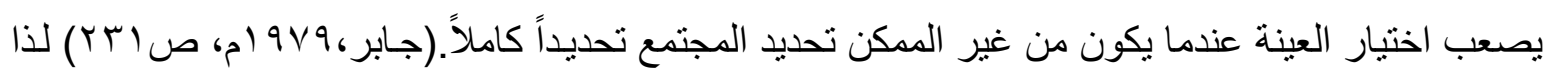
حدد الباحث مجتمع بحثه بطلاب الصف الثناني المتوسط في المدارس المتوسطة والثانويـة النهاريـة للبنين و البنات التابعة لمديرية تربية واسط.

\section{ثالثاً / عينة البحث الأسساسية :}

اختيرت عينـة البحثث مـن المجتمـع الإحصـائي للبحث ، بالأسـلوب العشـوائي ؛ لذا حددت مدرسـة للبنين

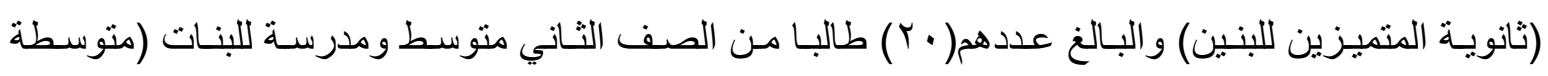

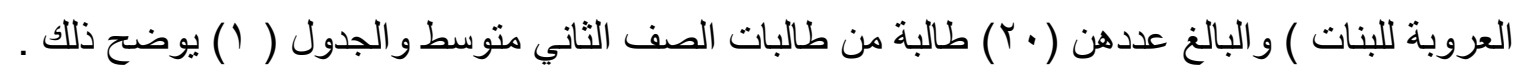
الجدول ( (1) عينة البحث موزعه على مديرية تربية واسط بحسب الجنس

\begin{tabular}{|c|c|c|c|c|c|c|}
\hline \multirow[t]{2}{*}{$\%$} & \multirow[t]{2}{*}{ المجموع } & \multicolumn{4}{|r|}{ الجنس } & \multirow[t]{2}{*}{ المديرية } \\
\hline & & $\%$ & الطالبات & $\%$ & الطلاب & \\
\hline $1 \ldots$ & $1 \ldots$ & 0 . & $r \cdot$ & 0 . & $r$. & تربية واسط \\
\hline
\end{tabular}

رابعًا /أداتا البحث

ا ـ محكات التصحيح: نظر اً لعدم توفر محكات ثابتـة نسبيا لتصحيح اختبار ات اكتسـاب المفاهيم النحويـة في البحوث التجريبية في البيئة العر اقية و العربية على حد علم الباحث ، لذا بنى الباحث هذا المحكات معتمدا على الدراسـات السـابقة والادبيات المتخصصـة بذللك، وكذلك على خبرتـه الميدانيـة، حيث بلـغ عدد المحكات (9) 
محكات (ملحق/( )، وقد عرض الباحث تلك المحكات على مجموعـة مـن الخبر اء المختصسين بمـادة اللغـة العربية وطر ائق تدريسها والقياس و التقويم، وقد حظيت جميعها بالقبول . r- اختبار المفـاهيم النحويـة : لعدم توفر اختبار اكتسـاب المفـاهيم النحويـة مقنن ويتصف بالصدق والثبـات،

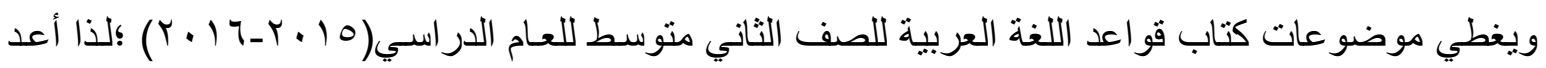
الباحث اختبار اً لقياس اكتساب المفاهيم النحوية؛ لمعرفة فاعلية محكات التصحيح المقترحة واستخر اج المحك المفضل الذي يعتمد عليه في تصحيح اختبار اكتساب المفاهيم النحوية ، وهو اختبار موضوعي مؤلف من

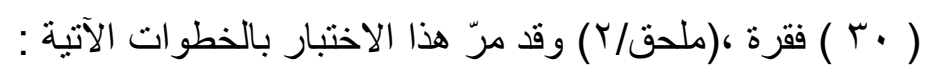
أـ تحديد المادة العلمية: حدد الباحث المادة العلمية التي سيعتمد اعداد الاختبار عليها بالموضو عات الموجودة في كتـاب قو اعد اللغـة العربيـة للصف الثـاني المتوسط على النحو الآتـي :( الاستثناء، والتمييز، و الحـال، و النداء، و النعت، و العطف، و البدل، التوكيد). ب - تحديد المفاهيم النحوية: بعد أن حدد الباحث المـادة العلميـة حلّل الموضو عات، ومن ثم حدّد المفـاهيم النحويـة الموجودة ضمن محتوى تلك الموضو عات، لغرض تحقيق هدف البحث مسترشداً بالعمليات الثتلاث التي تبناهـا وهي (تعريف المفهوم، وتمييزه، وتعميمه) كمعايير ووسائل ينبغي تو افر ها بغية تحليل المحتوى مفاهيمياً، ثم عرض لثن الباحث

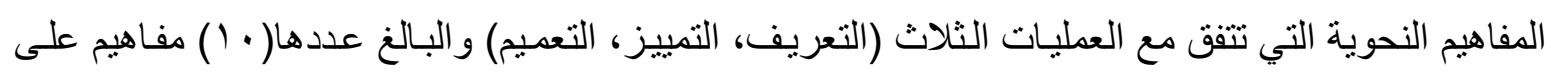

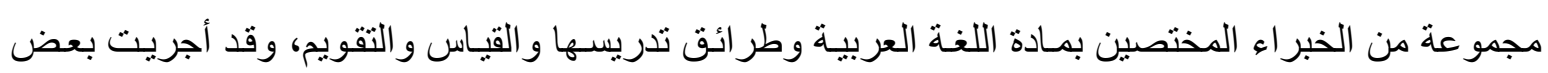

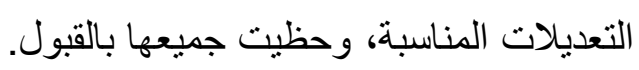
ج- صياغة الأهداف السلوكية : صـاغ الباحث الأهداف السلوكية للمفاهيم المحددة؛ إذ بلغ عددها (·r) هدفا سلوكيا ، لكل مفهوم واحد ثلاثة اهداف موزعة على المستويات الثلاثة (التعريف، التمبيز، التطبيق) د- صياغة فقرات الاختبار: اعتمد الباحث على الاختبار ات الموضدوعية من نوع "الاختيار من متعدد"؛ لمـا

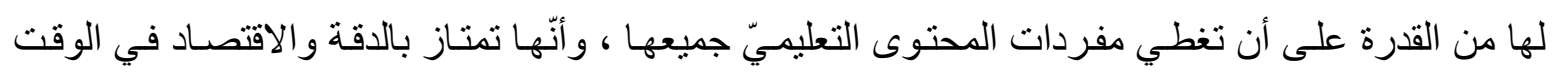

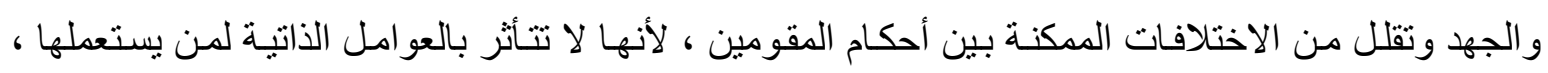

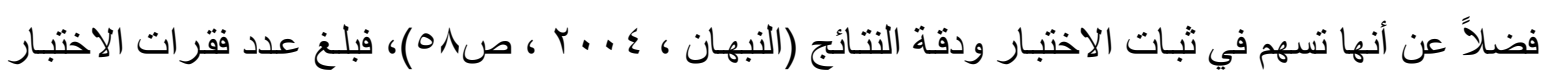

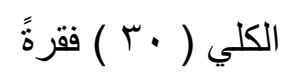

د - صدق الاختبار : للتحقق من صدق الاختبار وجعله محققاً للأهداف التي أُعدَّ من اجلها فقد عرض الباحث فقرات الاختبار التحصيلي واهدافه السلوكية على مجموعة من الخبر اء والمتخصصين في مناهج اللغة العربيـة وطر ائق تدريسها وفي مادة القياس والتقويم، لإبداء ملاحظاتهم في مدى صدق قياس فقرات الاختبار للأهداف

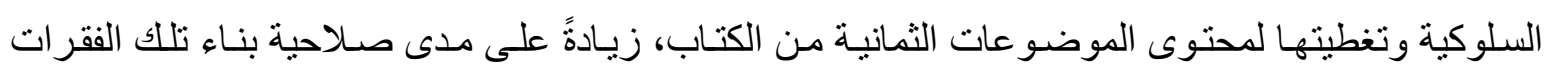
و المستويات التي تقيسها لغرض التحقق من الصدق الظاهري وصدق المحتوى. 
وبعد تحليل اجابات الخبر اء أجرى الباحث التعديلات اللازمة على بعض فقر ات الاختبار فأصبح الاختبار

$$
\text { في صورته النهائية في (ملحق/ب). }
$$

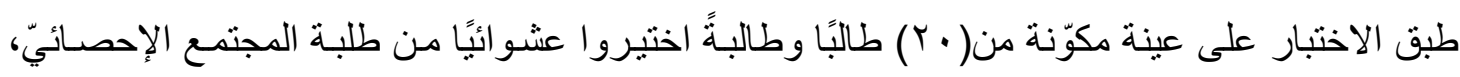
وقد طلب من الطلبة قراءة التعليمـات والفقرات، والاستفسـار عن أي غموض، وذكر الصـوبات التي قد

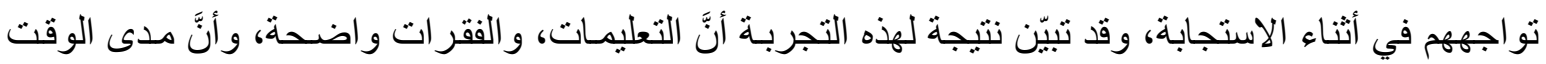

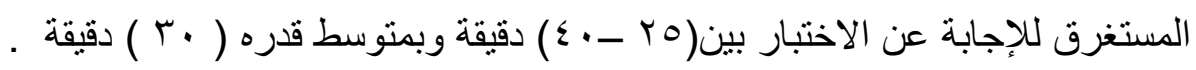

r ـ التحليل الاحصائي لفقرات الاختبار: Analysis statistical of The test items طبق الباحث الاختبار على عينة مماثلة لعينة البحث تكونت من( · . ( ) طالبٍ وطالبة ولتسهيل الاجر اءات الاحصائية فقد رثَّب الباحث الدرجات تنازلياً من أعلى درجـة إلى أدنى درجـة، ثم اختار العينتين المتطرفتين العليا والدنيا بنسبة(rV/.Y.)من افر اد العينة في كل مجمو عة، وفيما يأتي توضيح لإجر اءات التحليل الاحصـئي لققرات الاختبار:

\section{Difficulty test items صعوبة فقرات الاختبار:}

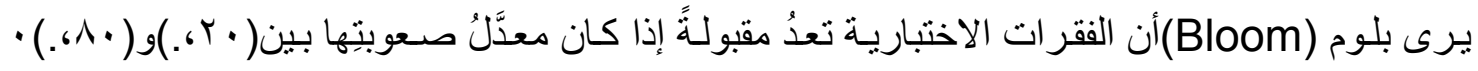
وبعد حسـاب معامـل الصـوبة لكل فقرة مـن الفقرات الاختباريـة ، اتضـح أنها

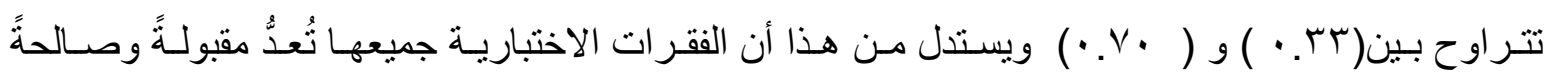
للتطبيق، والجدول( r )يوضح ذلك.

\begin{tabular}{|c|c|c|c|c|c|c|c|c|c|c|c|}
\hline 交 & 滒 & 予 & 滒 & 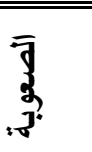 & 司 & ج大. & 泀 & 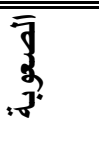 & 哥 & 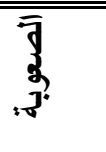 & 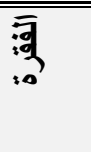 \\
\hline .01 & Yq & $\cdot r V$ & $\bar{r}$ & $\cdot . \leqslant r$ & 17 & $0 \leqslant 4$ & 11 & $\cdot r V$ & 7 & $\cdot . \leqslant \Lambda$ & $T$ \\
\hline 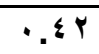 & $\overline{r V}$ & $\cdot r \Delta$ & $\overline{Y Y}$ & 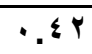 & IV & .09 & Tr & $\because \leqslant \Lambda$ & 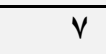 & 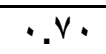 & $r$ \\
\hline$\because \mu \wedge$ & $Y \Lambda$ & . & $\overline{Y T}$ & $\because 0$. & 11 &. $.0 \mathrm{~V}$ & 14 & $\because 00$ & $\Lambda$ & ..$\leqslant \xi$ & $\bar{r}$ \\
\hline$\because \leqslant \Lambda$ & rq & $\cdot . \leqslant \Lambda$ & $Y \xi$ & $\because 0 \mathrm{~V}$ & 19 & 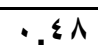 & $1 \varepsilon$ & $\because \leqslant \Lambda$ & 9 & T & $\xi$ \\
\hline$\cdot . \leqslant \wedge$ & $r$. & $\because \leqslant \Lambda$ & Yo & . & $r$. & 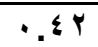 & 10 & $\cdot r \mu$ & 1. & .04 & 0 \\
\hline
\end{tabular}

(ب) (الجدول)

Discrimination of test items تمييز فقرات الاختبار 


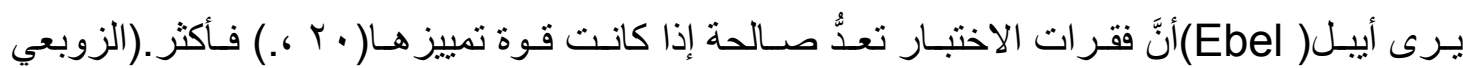

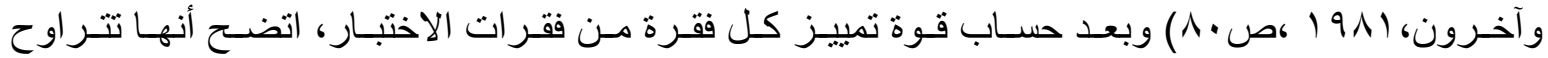

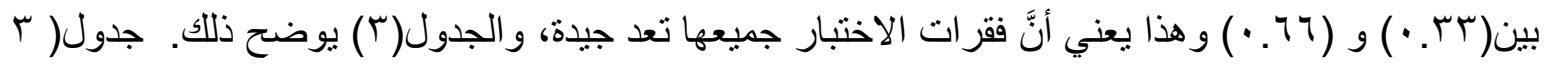

\begin{tabular}{|c|c|c|c|c|c|c|c|c|c|c|c|}
\hline 電 & 哥 & 哥 & 司 & 電 & 哥 & 電 & 漓 & 電 & 哥 & 電 & 滒 \\
\hline. .01 & YY & $\cdot r V$ & Y & $\because \leqslant Y$ & 17 & $\because \leqslant 4$ & 11 & $\cdot r V$ & 7 & $\because \leqslant \Lambda$ & $T$ \\
\hline . $\leqslant Y$ & $\overline{Y V}$ & 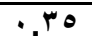 & $\overline{Y Y}$ & 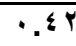 & IV &. .09 & TY & $\quad . \leqslant \Lambda$ & V & .97 & $r$ \\
\hline 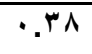 & YM & $\because \varepsilon$ & $r T$ & $\because 0$ & 11 & $\because . \mathrm{V}$ & $1 \pi$ & $\because 0$ & $\Lambda$ & . $\{\xi$ & $r$ \\
\hline$\quad . \leqslant \Lambda$ & rq & 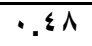 & $r \xi$ & $\because .0 \mathrm{~V}$ & 19 & $\quad . \leqslant \Lambda$ & $1 \varepsilon$ & $\quad . \leqslant \Lambda$ & 9 & . & $\xi$ \\
\hline$\because \leqslant \Lambda$ & $r$. & 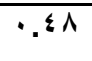 & ro & $\because \varepsilon$ & $r$. & $\because \leqslant r$ & 10 & $\because r \mu$ & 1. & $\because .04$ & 0 \\
\hline
\end{tabular}

هـ-؟ّ-فعالية البدائل المخطوءة (الممو هات أو المشتتات) attraction power of the alternatives the

بعد أن أجرى الباحث العمليات الاحصائية اللازمة لذلك، ظهر لديه أنَّ البدائل المخطوءة لفقرات الاختبار التحصيلي قد جذبت عدداً من طلاب المجموعة الدنيا اكبر من طلاب المجموعة العليا؛ لذا تقرر الابقاء عليها جميعها من دون حذف أو تعديل ،و الجدول( ؛ )يوضح ذلك.

\begin{tabular}{|c|c|c|c|c|c|c|c|c|c|c|c|}
\hline & & & & & & & & & \multicolumn{3}{|c|}{ الجدول(£) } \\
\hline $\begin{array}{l}\overline{3} \\
\text { 哥 } \\
\text { 武 }\end{array}$ & $\begin{array}{l}\text { 弯 } \\
\text { 事 }\end{array}$ & 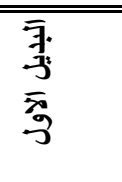 & 滒 & $\begin{array}{l}\overline{\bar{g}} \\
\text { 方 } \\
\text { 司 }\end{array}$ & 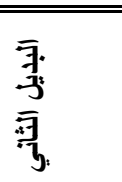 & $\begin{array}{l}\overline{\overline{3}} \\
\overline{3} \\
\overline{3}\end{array}$ & 滒 & $\begin{array}{l}\overline{\bar{a}} \\
\text { 方 } \\
\text { 司 }\end{array}$ & 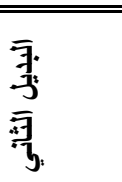 & $\begin{array}{l}\overline{3} \\
\overline{3} \\
\overline{3}\end{array}$ & 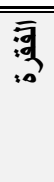 \\
\hline O.YY- & $\because \cdot V_{-}$ & $. .1 \leqslant-$ & $r 1$ & $.11-$ & $\because \cdot{ }_{-}-$ & $\therefore 11-$ & 11 & $\cdot 1^{\Lambda_{-}}$ & I.YY- & $\because \mu_{-}$ & 1 \\
\hline I.YY- & $\because V_{-}$ & IYY- & YY & $.1 \leqslant-$ & $.11-$ & $\because V_{-}$ & Ir & $\because \cdot T-$ & $.1 \leqslant-$ & $\because 1 \Lambda_{-}$ & $r$ \\
\hline$\ddots^{\top}-$ & $.1 \leqslant-$ & IYY- & $r Y$ & $.1 \leqslant-$ & IYY- & $\because 1 \Lambda_{-}$ & ir & $. .1 \leqslant-$ & IYY- & IYY- & $r$ \\
\hline .111 & $\because \cdot v_{-}$ & $.11-$ & $r \xi$ & . & $\because 1 \Lambda_{-}$ & $\therefore 11-$ & $1 \varepsilon$ & UYY- & $\because 1 \Lambda_{-}$ & $\therefore$ YY. & $\varepsilon$ \\
\hline$\because 1 \leqslant-$ & $.1 \leqslant-$ & IYY- & ro & $\cdot{ }^{\prime 1 \Lambda_{-}}$ & $\because V_{-}$ & $\because 11-$ & 10 & $. .11-$ & I.YY- & $. .1 \leqslant-$ & 0 \\
\hline$\cdot .1 \leqslant-$ & $\because \wedge^{\wedge}$ &.$^{\prime \Lambda_{-}}$ & YY & - & r. ro- & $\because .1 \Lambda_{-}$ & 17 & UYY & $.11-$ & $\because \cdot v_{-}$ & 9 \\
\hline $.1 \leqslant-$ & $.11-$ & $.1 \leqslant-$ & YV & IYY & . ro- & C.YY- & IV & $\cdot{ }^{\prime \prime} \Lambda_{-}$ & $\cdot{ }^{\prime 1} \Lambda_{-}$ & $.11-$ & $\bar{v}$ \\
\hline$\because \Lambda_{-}$ & $\because \Lambda_{-}$ & $\because 1 \leqslant-$ & YA & $.1 \leqslant-$ & $\because$ Y & $\therefore$ ros & 11 & $.11-$ & $911-$ & $.11-$ & $\Lambda$ \\
\hline U.YY- & $\because \cdot V_{-}$ & U.YY- & rq & $\cdot .1 \Lambda_{-}$ & $\because r-$ & $0.1 \leqslant-$ & 19 & $\cdot .1 \leqslant-$ & $\cdot .11-$ & $.1 \leqslant-$ & 9 \\
\hline$\because Y Y_{-}$ & $\because 11-$ & $.11-$ & $\mu$. & $.11-$ & $\cdot \wedge^{\prime}$ & $\cdot .1 \Lambda_{-}$ & $r$. & $\because V_{-}$ & $\because \wedge_{-}$ & $\ddots^{\prime \Lambda_{-}}$ & 1 \\
\hline
\end{tabular}

ثنبات الاختبار:

استعمل الباحث طريقة ألفا كرونباخ لاستخر اج الثبات للفقرات الموضوعية فبلغ( V9. • ) وهو معامل

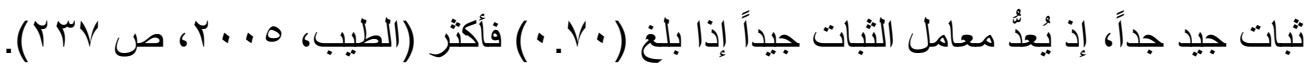
خامساً: الوسائل الإحصائية الوسائل الإحصائية التي استعملت في هذا البحث حسبت بوساطة برنامج الحاسوب الآلي (SPSS) هي: 
ا ـ معادلة (كاب ) مربع كاب Square - Chi: لمعرفة دلالة الفروق في عدد الخبر اء الذين و افقوا على

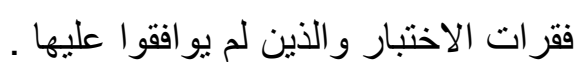

r. معامـل ارتبـاط بيرسـون Person Correlation Coefficient: لمعرفـة الثبـات بطريقة إعـادة

الاختبار ، ولحساب العلاقات الارتباطية بين محكات التصحيح . r. تحليل التباين الاحادي لمعرفة الفروق بين محكات التصحيح .

ع. الوسط المرجح لمعرفة اكثر المحكات تفضيلا من قبل الخبراء

๑. معامل الصعوبة: استعملت هذه الوسيلة لحساب معاملات صعوبة فقرات الاختبار :

$$
\text { ص= }
$$

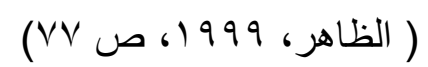

ن

ع. معامل تمييز الفقرة : استعملت هذه الوسيلة لحساب معاملات القوة التمييزية لفقرات الاختبار

$$
\text { ت = (ن ص ع) + (ن ص د) }
$$

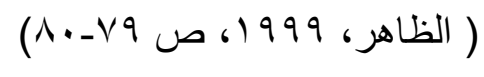

هـ فعاليـة البـائل المخطوءة : استعمل الباحث هذه الوسيلة لقياس فعاليـة البـدائل غير الصـحيحة لفقرات الاختبار التحصيلي .

$$
\text { فعالية البدائل المخطو عة= (ن ع م) - (ن د م) }
$$

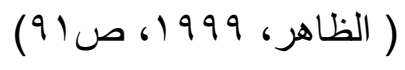

\section{الفمل الغامسل: نتانجه البمث}

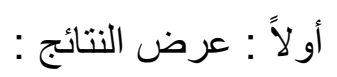

السؤ ال : ما المحكات المفضلة من بين تلك المحكات المقترحة لتصحيح اختبـار اكتسـاب المفاهيم النحويـة عند طلبة المرحلة المتوسطة؟ للإجابة عن هذا السؤال، استعمل الباحث عدة طرق احصائية للإجابة عن هذا السؤال، وهي كالآتي: الطريقة الاولى: لتقدير الافضلية النسبية لكل محك حلت تقديرات الخبر اء البـالغ عدده ( • () خبراء على مقياس متدرج احصائيا باستخدام معادلة ( فيشر Fisher ) لحساب الوسط المرجح لكل محك الذي يمثل وزن افضـليته، وبعد حسـاب ذلك ظهرت الاوزان المرجحة و النسـب المئويـة على النحو الآتي: و الجدول ( 0 ) يوضح ذلك . الجدول ( 0 ) المحكات وافضليتها النسبية بحسب الوسط المرجح و النسبة المئوية

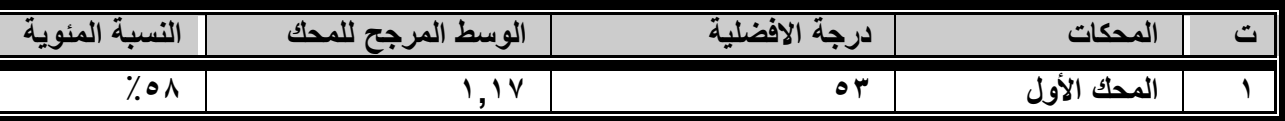




\begin{tabular}{|c|c|c|c|c|}
\hline$\% \wedge r$ & 1,79 & Vo & المحك الثاني & $\bar{r}$ \\
\hline$\% 7 \mathrm{~V}$ & $1, r o$ & 71 & المحك الثالث & $r$ \\
\hline$\% \Delta r$ & $1, \cdot \varepsilon$ & $\varepsilon V$ & المحك الرابع & $\varepsilon$ \\
\hline$\%$ \% & $\cdot, 0 \mathrm{~V}$ & Y7 & المحك الخامس & 0 \\
\hline$\% \wedge \theta$ & $1, \times 1$ & VV & المحك السـادس & 7 \\
\hline$\%$ \% & $1, \leqslant \wedge$ & IV & المحك السابع & V \\
\hline$\%$ ro & $\cdot, \times 1$ & rr & المحك الثامن & $\Lambda$ \\
\hline$\% 1 \mathrm{~V}$ & $\cdot, r o$ & 17 & المحك التاسع & 9 \\
\hline
\end{tabular}

يتضـح من الجدول ان المحك السـادس حصـل على اعلى نسبة مئويـة مقدار ها(10\%)، ومـن ثم المحك

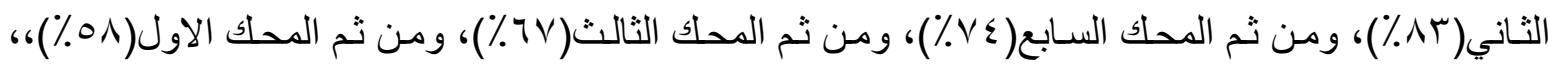

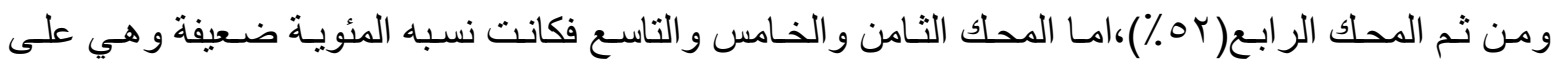

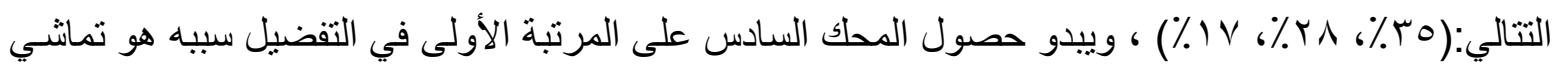
هذا المحك مـع المنهج المنطقي العقلي؛ إذ يرى ان هنالك اجابـات غير منطقية وهذه الاجابـات لا تعطى لها درجة ، اما الاجابات المنطقية تعطى لها درجة بحسب الترتيب فالمستوى الأول من اكتساب المفهوم(التعريف) له درجة مقدار ها( ( )، و المستوى الثاني من اكتساب المفهوم (التمييز) له درجة مقدارها(؟)، و المستوى الثالث من اكتساب المفهوم لله درجة مقدار ها(ץ)، اما المحك الثاني الذي حصل على المرتبة الثانية في التفضيل سببه هو الثياع الاكثر تعاملا من قبل الباحثين، اما المحك السابع الذي حصل على المرتبة الثالثة في التفضيل سببه انه يعد جزء من المحك السادس فهو ايضا يعتمد على التدرج في اعطاء الدرجة بحسب مستوى الصسعوبة الا

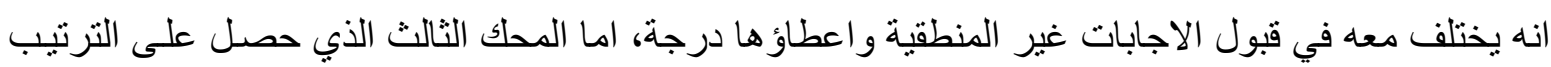
الر ابع فان سبب تفضيله هو الاعتمـاد على جميع مستويات اكتسـاب المفهوم فالذي يكتسب المفهوم يجب ان يعرف ويميز ويطبق، امـا المحك الأول الذي حصل على المرتبـة الخامسـة في التفضيل سببه هو ان عمليـة اكتساب المفهوم لا تختلف عن التحصيل. امـا بقية المحكات كان سبب النسب الضعيفة فيها هو الحكم على هوي اكتساب المفهوم بكامله من خلال مستوى واحد فقط كما في المحك الرابع و الثامن والتاسع، اما المحك الخـامس فان سبب ضعفه هو عزل كل مستوى من مستويات اكتساب المفهوم و اعطائه درجة خاصة به. الطريقة الثانية: لمعرفة الافضلية النسبية للمحكات استعمل الباحث تحليل التباين الاحسادي لمعرفة الفروق بين المتوسطات الحسابية، وبما ان مستوى التصحيح في ضوء المحكات ليس على مستوى واحد؛ إذ كان المحك الأول من( • (ب) درجة، و المحك الثاني والثالث و الر ابع و الثامن و التاسع من( • () درجات، و المحك الخامس من

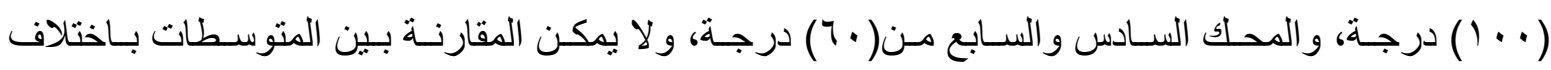
مستويات التصحيح ؛لذا لجأ الباحث إلى توحيد الدراجات واعتمـاد النسبة المئويـة، فاصبحت جميع الدرجات موحدة من ( · · ( ) درجة، ومن ثم استعمل الباحث تحليل التباين الاحادي لإجابات الطلبة على اختبار اكتسـاب

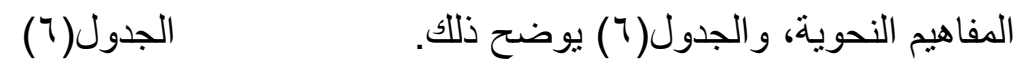

نتائج تحليل التباين الأحادي لالالة الفرق بين درجات المحكات التسعة

\begin{tabular}{|c|c|c|c|c|}
\hline النسبة الفائية & 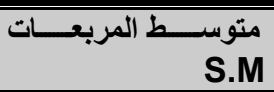 & d.f درجة الحرية & مجـــــوع المربعـــات & مصدر التباين \\
\hline \multirow{3}{*}{$r \leq .0 \leqslant 7$} & rqY $\{. \wedge \leq q$ & $\Lambda$ & 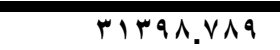 & بين المجموعات \\
\hline & $9 r .9 \cdot r$ & rol & $07 / Y \varepsilon . . V 0$ & داخل المجموعات \\
\hline & & $r \Delta q$ & AVOYY.ATE & الكلي \\
\hline
\end{tabular}




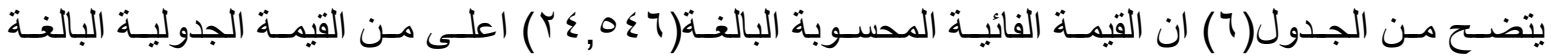

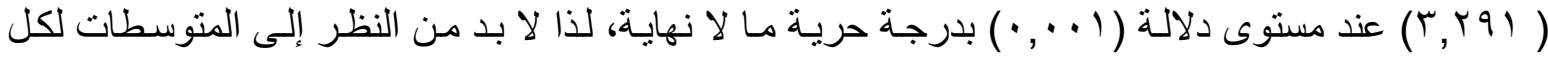
محك تصحيح ومعر فة الفروق فيما بينها من خـلال الاعتمـاد على محك داخلي هو المتوسط العام لمتوسطات محكات التصحيح، واعتماد الترتيب التصاعدي من حيث الأفضلية ؛ والجدول (V) يوضح ذللك.

\begin{tabular}{|c|c|c|c|c|}
\hline الاتحراف المعياري & المتوسط الحسابي & العينة & المحكات & $ت$ \\
\hline $1 \cdot, r v \leq$ & $\Lambda \varepsilon, \vee 0$ & $\varepsilon \cdot$ & المحك الأول & 1 \\
\hline $17,01 \varepsilon$ & $V \leqslant, r_{0}$ & $\varepsilon \cdot$ & المحك الثاني & $r$ \\
\hline $1 \varepsilon, \wedge \leqslant 1$ & $\Lambda \leqslant, 0$. & $\varepsilon \cdot$ & المحك الثالث & $r$ \\
\hline $1 \cdot, 1 \mu v$ & $\wedge 0,1$. & $\varepsilon \cdot$ & المحك الرابع & $\varepsilon$ \\
\hline $1 \cdot, \cdot 7 \leq$ & $9 Y, 0$. & $\varepsilon \cdot$ & المحك الخامس & 0 \\
\hline$r \cdot, \leqslant q r$ & $T \leqslant, Y O$ & $\varepsilon$ & المحك السادس & 7 \\
\hline $9, \wedge 79$ & $\Lambda \varepsilon, 1 T$ & $\varepsilon \cdot$ & المحك السابع & $\mathrm{V}$ \\
\hline $9, \wedge 79$ & $\Lambda \varepsilon, 1 \mu$ & $\varepsilon \cdot$ & المحك الثامن & $\Lambda$ \\
\hline$r, \vee \wedge q$ & $99, \cdots$ & $\varepsilon \cdot$ & المحك التاسع & 9 \\
\hline $10,71 \leq$ & $\Lambda r, v r$ & $r 9$. & \multicolumn{2}{|c|}{ المجموع } \\
\hline
\end{tabular}

يتضح من الجدول(V) ان المحك السادس له المرتبة الأولى من حيث الافضلية في التصحيح ؛ إذ كان

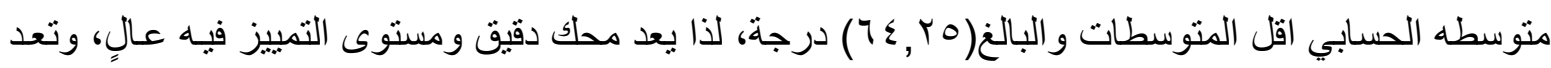
الدرجة التي يحصل عليها الطالب من خلاله هي اقرب لبيان المستوى الحقيقي لاكتسابه للمفاهيم النحويـة، ومن ثم يأتي بعده من حيث الافضلية بحسب التتالي (المحك الثاني، و السـابع، والثالث، والأول، الرابع، و الثامن، و الخـامس، والتاسـع) ، وكذلك يتضـح من خـلال النظر إلى المتوسطات ان المحكـات الثلاثذة الأولى اقل من المتوسـ العـام لمتوسطات المحكـات، بينمـا المحكـات السـتة المتبقيـة اعلى مـن المتوسـط العـام الذي قدره (Ar,Vr)

الطريقة الثالثة: استخرج الباحث العلاقات الارتباطية بين درجات الطلاب في اختبار اكتسـاب المفاهيم النحويـة في ضوء محكات المقترحة لتصحيح ذللك الاختبار ، وقد استخرجت النتائج عن طريق معامل ارتباط بيرسون،

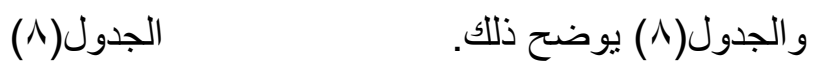

\begin{tabular}{|c|c|c|c|c|c|c|c|c|c|}
\hline$\cdot, \wedge \mid Y$ & r, & ?,qY. & י, & $1, \cdots$ & \& & (9) & ${ }^{\prime, A r}$ & & المحك الأول \\
\hline$\cdot, 094$ & , & $\cdot, \vee \vee \leqslant$ & $\cdot, 44$ & $\cdot, A Y Y$ & $\because, \nabla V$ & $\cdot, 7 \cdot 7$ & & & المحك الثاني \\
\hline$\cdot, \wedge \mid r$ & ${ }^{\prime}, Y_{1}$ & •, & $\cdot{ }^{9}{ }_{v}$ &., 940 & O & & & & المحك الثالث \\
\hline., $10 \mathrm{~V}$ & , ro & $\cdot, 7 \wedge \wedge$ & $\cdot, r$ & צ & & & & & المحك الرابع \\
\hline$\cdot, \wedge \mid r$ & r & $\cdot, 94$. & י, & & & & & & المحك الخامس \\
\hline י,人ץ० & $\cdot, r \xi$ & $\cdot, V \leqslant \leqslant$ & & & & & & & المحك السادس \\
\hline
\end{tabular}




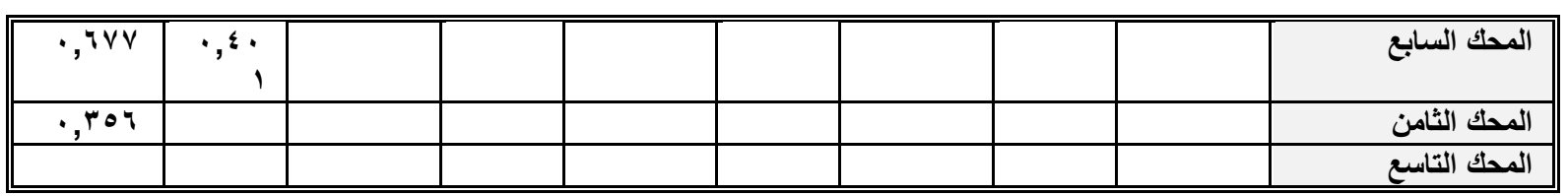

يتضـح مـن الجدول(^) ان جميع المحكـات لهـا ارتباطـات فيمـا بينها مـا عدا المحلك الرابع و السـادس،

وكذلك المحك الر ابع و الثامن، وكذلك المحك الر ابع والتاسع، واخير ا المحك السادس و الثنامن عند مستوى دلالة

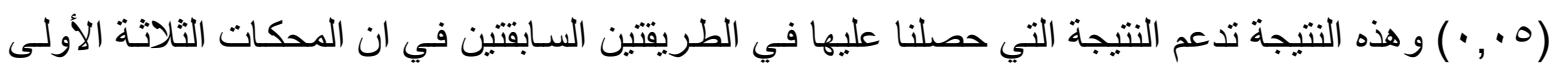
بحسب التفضيل و هي(السادس و الثاني و السابع) بينهم علاقات ارتباطية دالة، وهذا يثجع الألفة الموجودة بين تللك المحكات و امكان جمعها في محك واحد.

\section{الاستتنتاجات:}

في ضوء النتائج التي توصلت إليها هذه الدراسة يمكن استتناج ما يأتي: ( أنَّ محكات التصحيح المفضلة الثناثة الأولى بحسب الترتيب هي(السادس، والثاني، والسابع). r- أنَّ محكات التصحيح المفضلة الثناثة الأولى بحسب الترتيب هي(السادس، والثاني، و السابع) بينها علاقات ارتباطية. r- أنَّ محكات التصحيح المفضلة الثلاثة السابقة يمكن الاعتماد على جميعها وجعلها محكا واحدا، وعلى النحو الآتي: الذي يتمكن من هدفين من الاهداف الثلاثة: "التعريف، و التمييز، و التطبيق" يعد مكتسبا للمفهوم، وهن

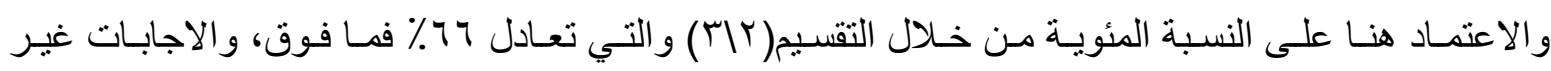
المنطقية لا تعطى لها درجة والاجابات المنطقية تعطى لها درجة بحسب التدرج، و التدرج هو ان نعطي درجة لمستوى التعريف، ومن ثم نعطي درجة مضـاعفة لمستوى التمييز، ومن ثم نعطي درجهة مضـاعفة مرتين

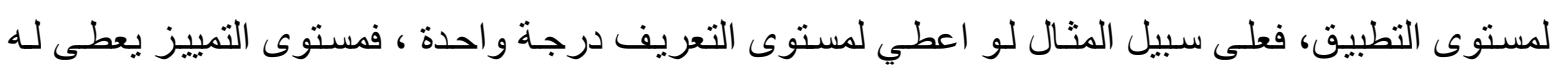
درجتان، ومستوى التطبيق يعطى له ثلاث درجات. وبذلك قد عالجنا الفرق بين الفقرات التي تقيس مستويات

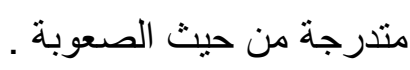

عـ أنَّ محكات التصحيح الثلاثتة الوسط بحسب الافضلية هي(الثالث، والأول، والرابع)، وهذه المحكات لا

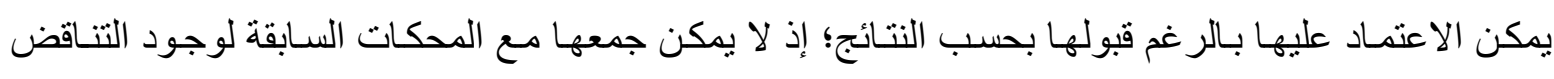
و عدم امكانية توحيدها.

هـ أنَّ محكات التصحيح الثلاثة المنخفضة بحسب الافضلية هي (الثامن، والخامس، والتاسـع)، وهذه المحكات لا يمكن الاعتماد عليها بحسب النتائج لإنخفاضها في الافضلية.

\section{التعوصبات: Recommendations}

بنـاءٌ على مـا تقدم من استتعر اض نتائج هذه الدراسـة واستنتاجاتها، يمكن تقديم التوصيات التربويـة العلميـة 
1.إعادة النظر في تصحيح اختبار ات اكتسـاب المفاهيم في جميع علوم اللغـة العربية، والاعتمـاد على محك علمي الذي حصلت هذه الدر اسة عليه. r. اعتماد هذا المحك المفضل التي توصلت هذه الدراسة اليه في العلوم الانسانية والعلمية الأخرى. r. التشجيع على الاهتمام ببناء محكات تصحيح للاختبار ات و المقاييس التي تحتاج إلى ضبط ودقة في عملية تصحيحها ؛ لبيان المستوى الحقيقي للمتعلم في المؤسسات التربوية.

Suggestions : المقترحات:

استكمالًا لهذه الدراسـة، يقترح الباحث إجر اء در اسـات وبحوث تربوية في مجال بنـاء محكات تصحيح

للاختبار ات و المقاييس، منها:

. اكتشـاف محكـات تصحيح دقيقة وواضـحة لمـادة التعبير التحريـري و الثنفوي ليس فقط توزيع الدر اجات

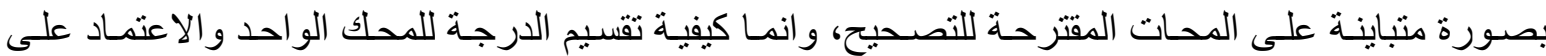
الاصالة والتكر ار و المرونة في ذلك.

r. تقويم مناهج اللغة العربية في ضو ء محكات عالمية في بناء المناهج. r. إعداد برامج تدرييية لتتمية بناء محكات التصحيح عند المدرسين .

\section{المصادر العربية والاجنبية}

الأمام ، مصطفى ، واخرون ـ التقويم والقياس ، بغاد : دار الحكمة ، ـ99 ام

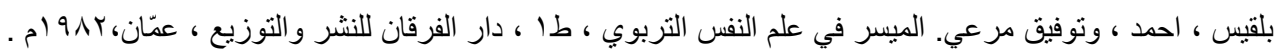

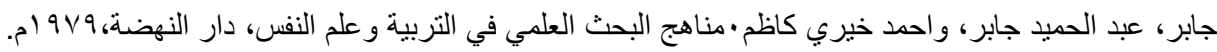

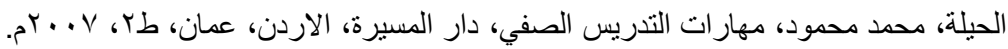

الدبور، ختام مصطفى رجب، أثر توظيف نموذج جانيه في اكتساب مفاهيم النحو لاى طالبات الصف السادس الاساسي الاسي

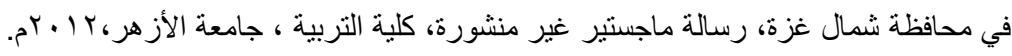

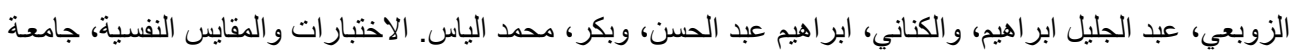

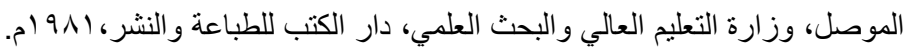

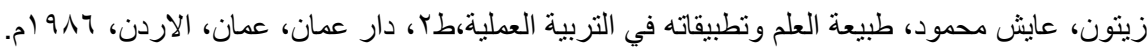

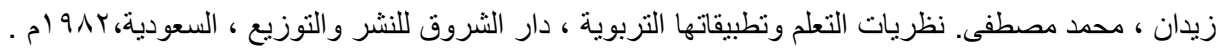

سـعادة،جودة، و اليوسـف، جمـال، تـدريس مفـاهيم اللغـة العربيـة و الرياضـيات و العلـوم و التربيـة الاجتماعيـة، طا، دار

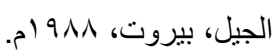

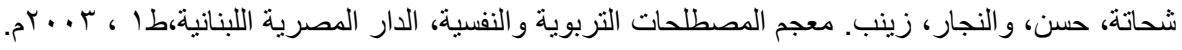

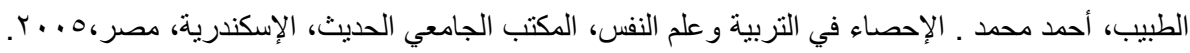

الطيطي، محمد حمد. تنمية قدرات التفكير الابداعي، دار المسيرة للنشر والتوزيع والطباعة، عمان، الاردن، الطبعة ولئ

الثالثة، V + . r.م.

الظاهر ، زكريا محمد وآخرون ـ مبادئ القياس و التقويم في التربية ، دار الثقافة للنشر و التوزيع ، عمان ، 999 ام.

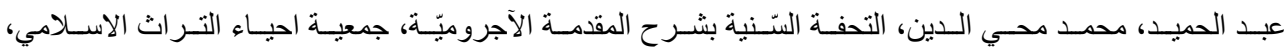

الكويت، 10 إهـ. (10.

عامر، طارق عبد الرؤوف محمد، دراسات في اعداد المعلم، دار اليازوري، عمان، الاردن، ل . بrم. 
الكرعاوي، ليث صـاحب شـاكر، تقويم أداء مدرسي اللغة العربية في تدريس مـادة طر ائق التدريس في معاهد إعداد

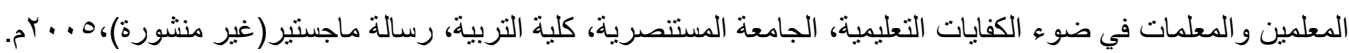

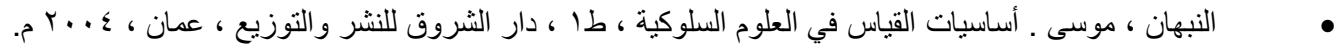

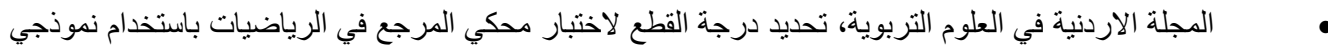

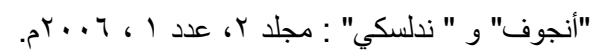

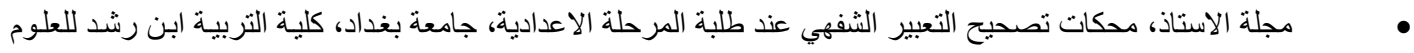

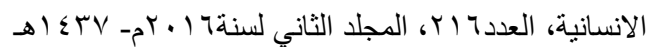

مجلة دراسات تربوية واجتماعية، تقويم الاختبارات التحصيلية للمعلم الجامعي بكلية التربية، المجلد الثالث عشر، العدد

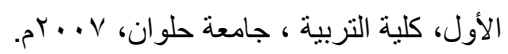

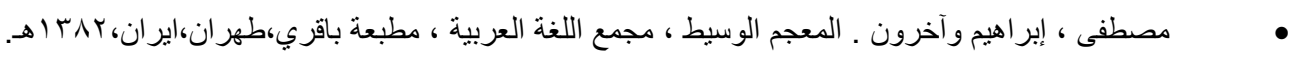

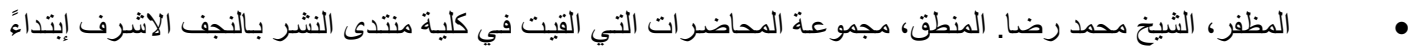

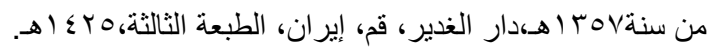

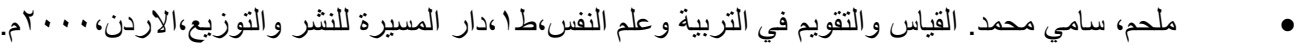

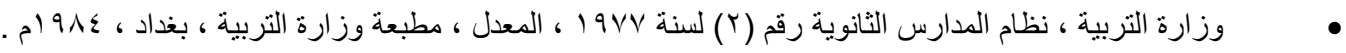

- $\quad$ Bloom, B, S , and other: Handbook on formative and

summative of studentlearning. evaluation York, McGraw-Hill , (1977).

- $\quad$ Good Carter .V. Oictionary of Education . Mc - Graw -Hill book . Co.1973

(l) (1) (1)

م/استباتة آراء الخبراء حول صلاحية محكات تصحيح اختبار اكتساب المفاهيم النحوية

: المحترم :

الأستاذ الفاضل .

السلام عليكم ورحمة الله وبركاته ...

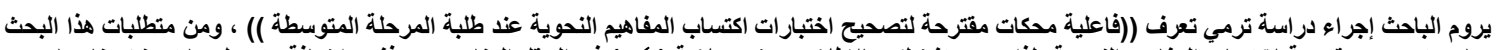

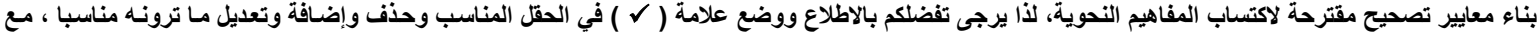

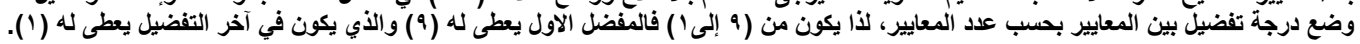

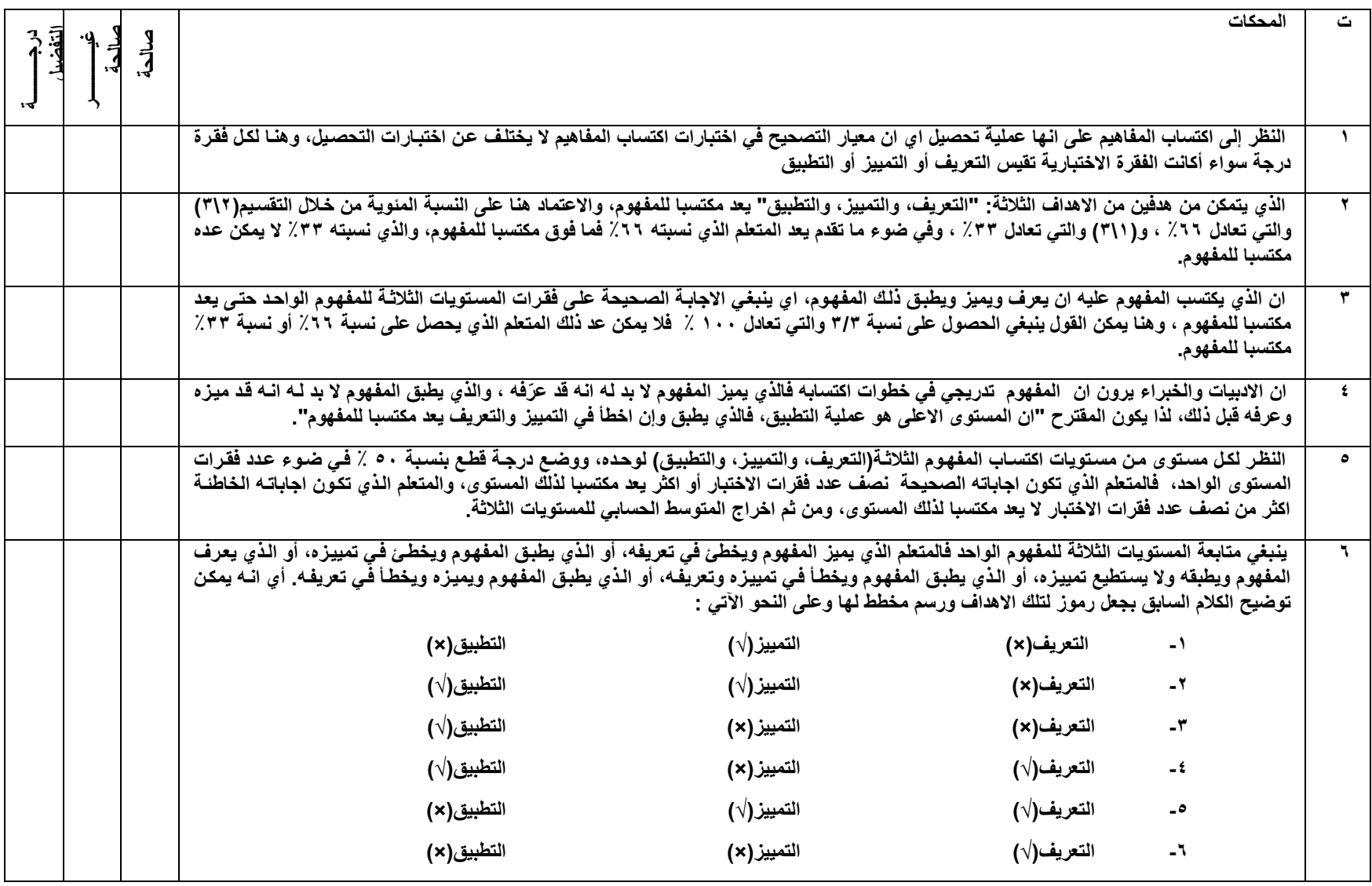




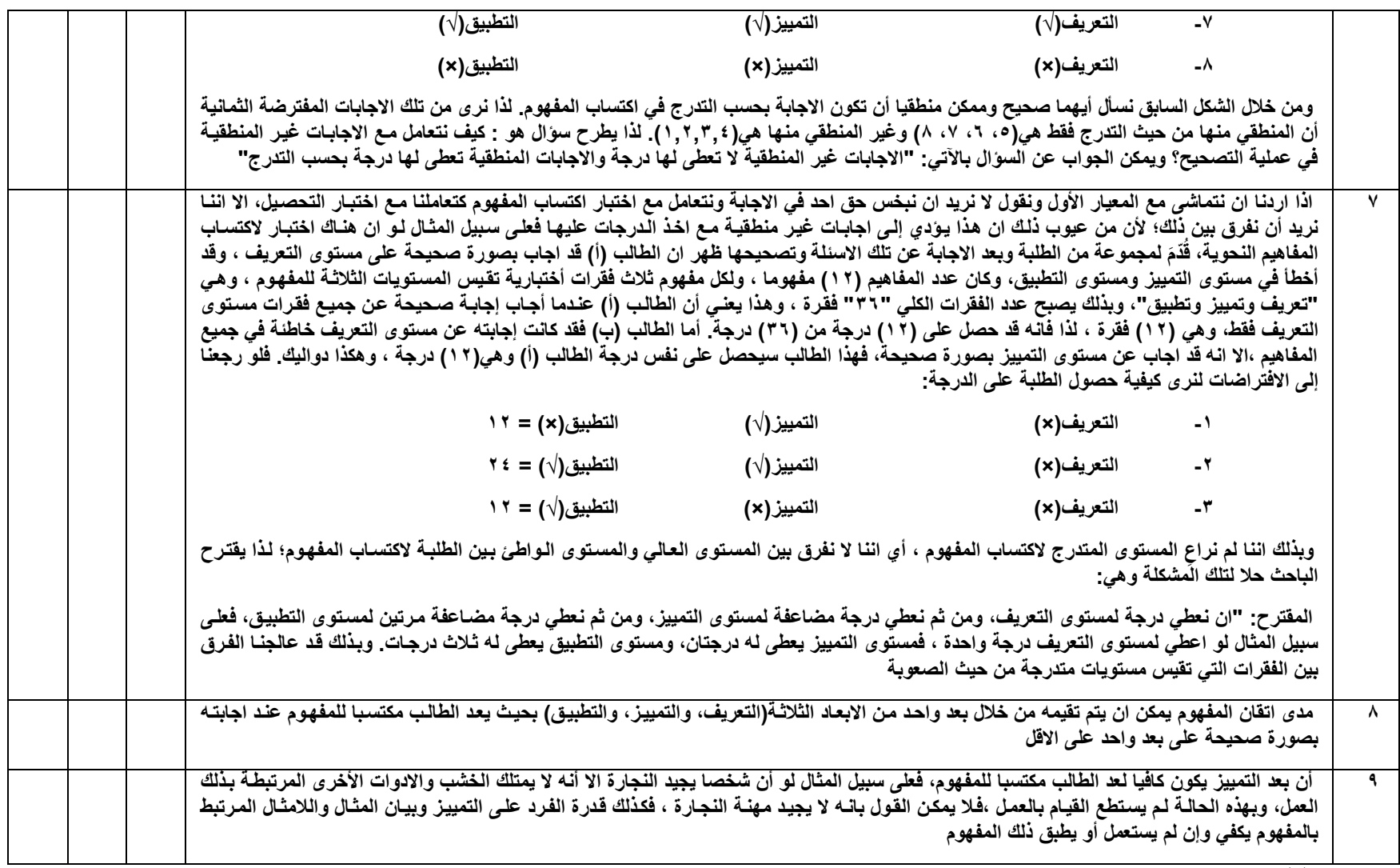

الملحق(ب)

م I إستبانة آراء الخبراء بثأن صلاحية فقرات اختبار اكتساب المفاهيم النحوية

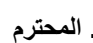
الأستاذ الفاضل .

تحية طيبة

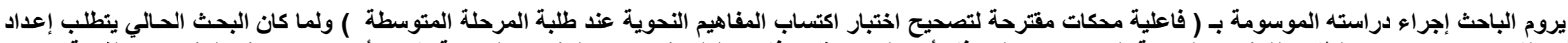

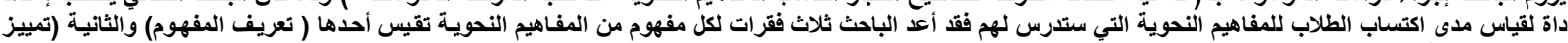

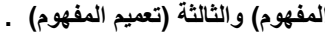

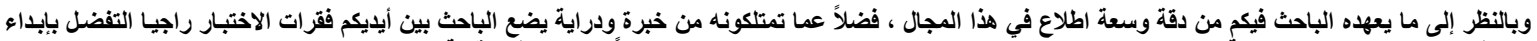

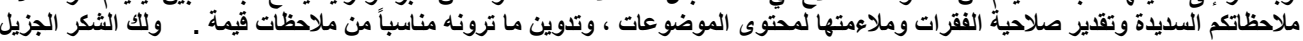

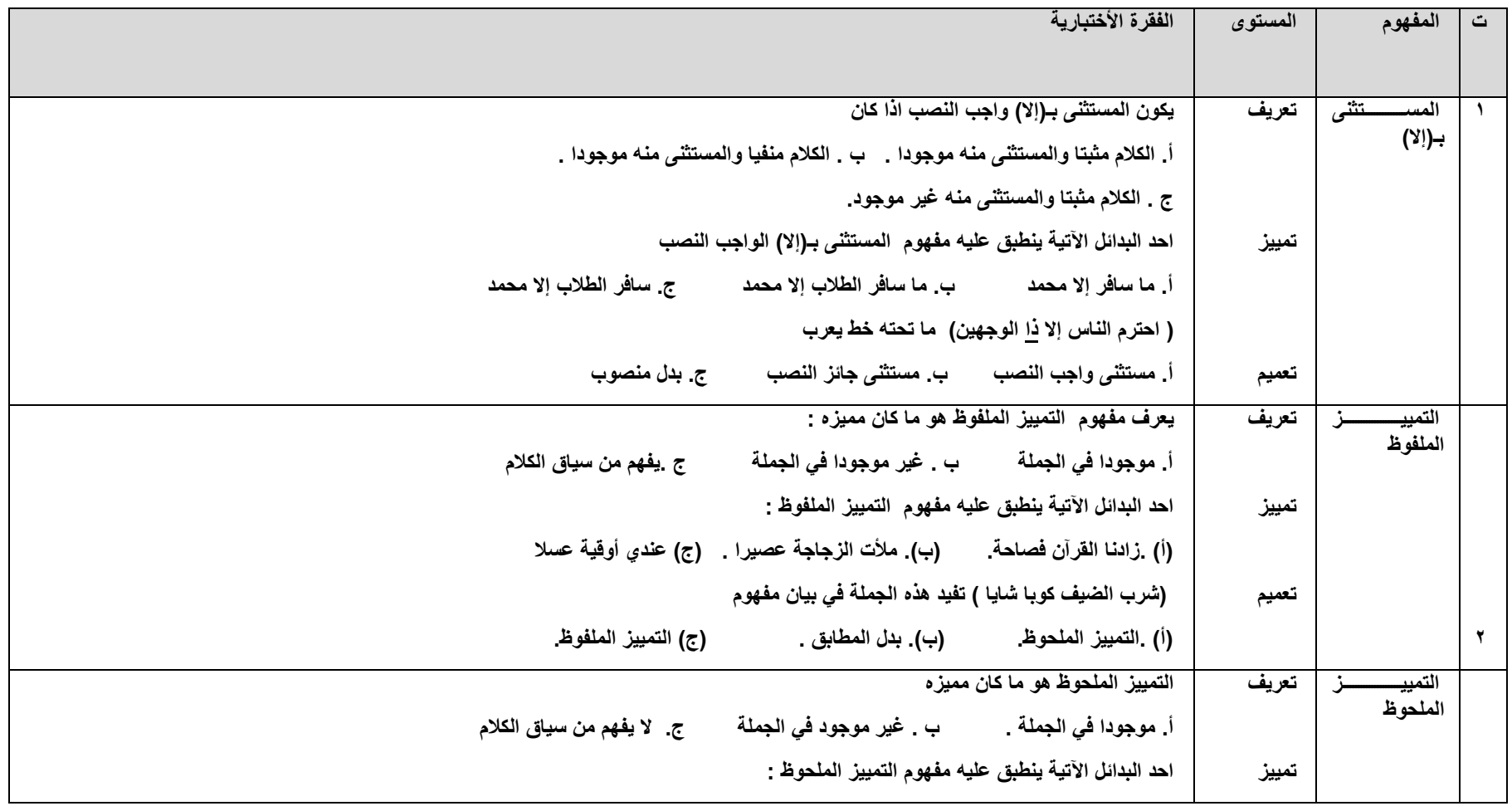




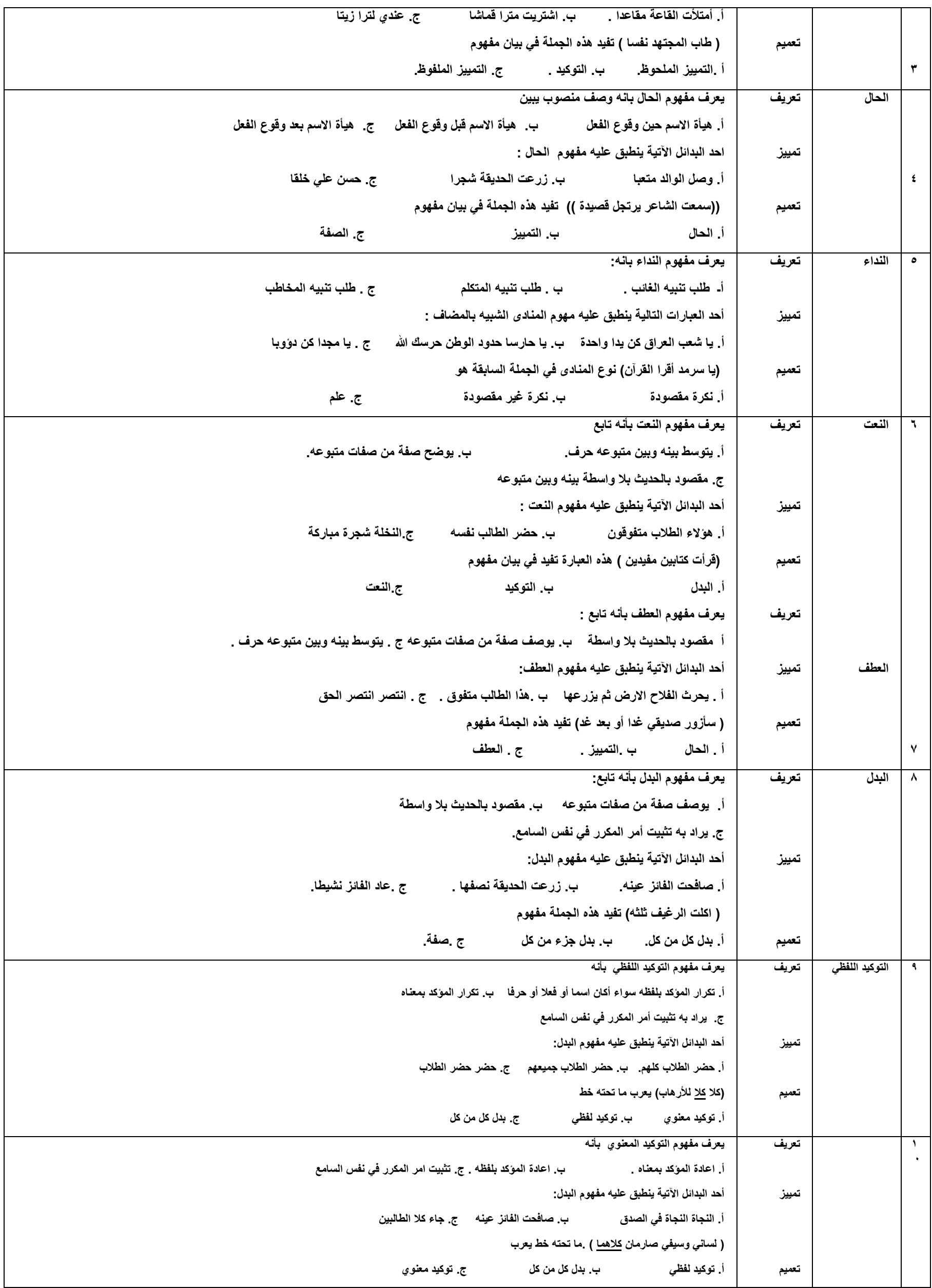




\begin{tabular}{|c|c|}
\hline & الملحق(") - آ) \\
\hline & 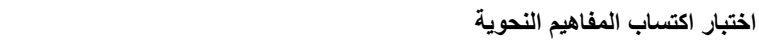 \\
\hline & السؤال الأول / ضع دائرة حول حرف الاختيار الصحيح. \\
\hline & 1. يكون المستثنى بـ(إلا) واجب النصب اذا كان \\
\hline ج ـ ـ الكلام مثبتا والمستثى منه غير موجود. & أ. الكلام مثبتا والمستثى منه موجودا ـ..الكلام منفيا والمستثنى منه موجودا . \\
\hline & r. يعزّف مفهوم التمييز الملفوظ بأنه ما كان مميزه : \\
\hline ج يفهم من سياق الكلام & ب غير موجودا في الجملة \\
\hline & ك. يعزَف مفهوم التمييز الملحوظ بأنه ما كان مميزه \\
\hline ج. ل ا يفهم من سياق الكلام & 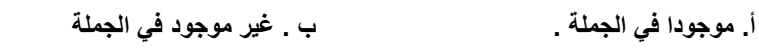 \\
\hline & ؛. يعزَف مفهوم الحال بانه وصف منصوب يبين \\
\hline ج. هيئة الاسم بعد وقوع الفعل & 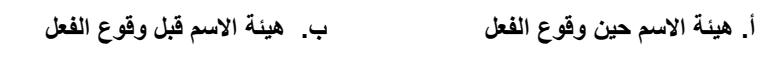 \\
\hline & •ـ ـ يعزَف مفهوم النذاء بانه: \\
\hline ج طلب تتبيه المخاطب & أـ طلب تتبيه الغائب . \\
\hline & لـ يعزَف مفهوم النعت بأنه تابع \\
\hline ج. مقصود بالحايث بلا واسطة بينه وبين متبوعه & ب. يوضح صفة من صفات متبوعه. \\
\hline & V ل يعرّف مفهوم العطف بأنه تابع : \\
\hline ج ـ يتوسط بينه وبين متبوعه حرف . & ب. يوصف صفة من صفات متبوعه \\
\hline & 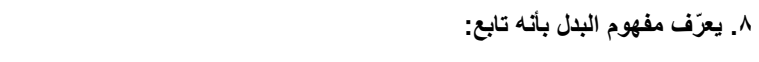 \\
\hline ج. يراد به تثبيت أمر المكرر في نفس السامع. & أ. يوصف صفة من صفات متبوعه \\
\hline & 9. يعرَف مفهوم التوكيد اللفظي بأنه \\
\hline ج. يراد به تثبيت أمر المكرر في نفس السامع & 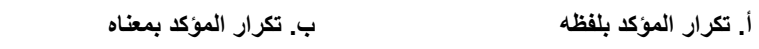 \\
\hline & • ا ـ يعرّف مفهوم التوكيد المعنوي بأنه \\
\hline ج. تثبيت امر المكرر في نفس السامع & 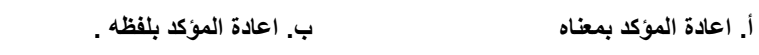 \\
\hline & السؤال الثاني/ ضع دائرة حول حرف الاختيار الصحيح. \\
\hline & 1 1. احد البدائل الآتية ينطبق عليه مفهوم المستثنى بـ(إلا) الواجب النصب \\
\hline ج. سافر الطلاب إلا محمد & 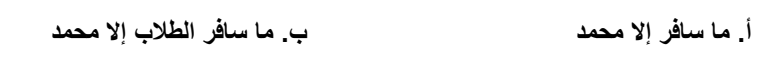 \\
\hline & r r. احد البدائل الآتية ينطبق عليه مفهوم التمييز الملفوظ : \\
\hline 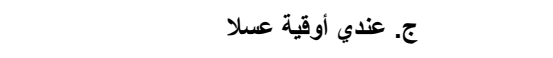 & 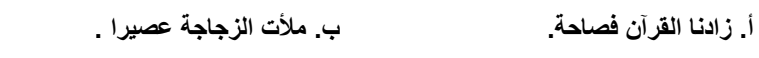 \\
\hline & r ا ـ. احد البدائل الآتية ينطبق عليه مفهوم التمييز الملحوظ : \\
\hline 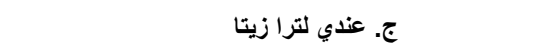 & 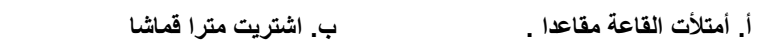 \\
\hline & ؛ ا. احد البدائل الآتية ينطبق عليه مفهوم الحال : \\
\hline ع. حَسُنَ عليّ خُلُقا & ب. اعت الحيقة شجرا \\
\hline & ه 1 ـ أحد العبارات الآتية ينطبق عليه مفهوم المنادى الثبيه بالمضاف : \\
\hline 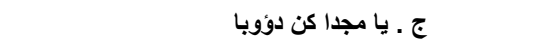 & ب. با حارسا حدود الوطن حرسك الله \\
\hline & 19. أحد البدائل الآتية ينطبق عليه مفهوم النعت : \\
\hline 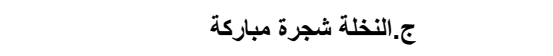 & أ. هؤلاء الطلاب متفوقون \\
\hline & V ا ـ أحد البدائل الآتية ينطبق عليه مفهوم العطف: \\
\hline 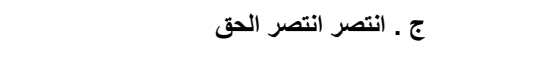 & أ يحرث الفلاح الارض ثم يزرعها \\
\hline & 1 1 ـ. أحد البدائل الآتية ينطبق عليه مفهوم البدل: \\
\hline ج عاد الفائز نشيطا. & 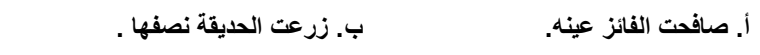 \\
\hline & 9 1 1 ـ أحد البائل الآتية ينطبق عليه مفهوم التوكيد اللفظي: \\
\hline 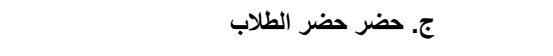 & ب. حضر الطلاب جميعهم \\
\hline & • r. أحد البدائل الآتية ينطبق عليه مفهوم التوكيد المعنوي: \\
\hline ج. جاء كلا الطالبين & أ. النجاة النجاة في الصدق \\
\hline & السؤال الثالث / ضع دائرة حول حرف الاختيار الصحيح. \\
\hline & 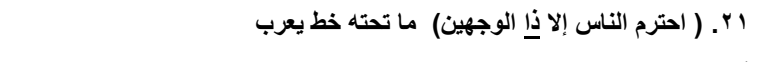 \\
\hline ج. بلل منصوب & أ. مستثى واجب النصب \\
\hline
\end{tabular}


ا r r r. (شرب الضيف كوبا شايا ) ما تحته خط يعرب

\section{ج. تمييز ملفوظ. \\ ج. تمييز الملفوظ.}

ج. صفة

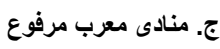

ج. نعت

ج. عطف

ج مفة.

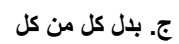

ج. ت توكيد مغنوي

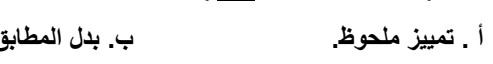

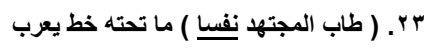

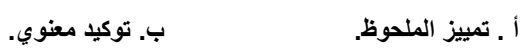

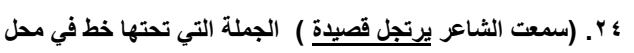

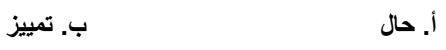

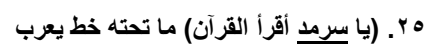

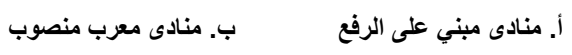

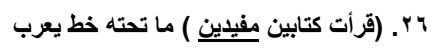

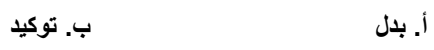

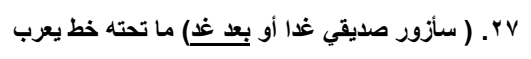

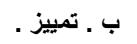
أ . حال

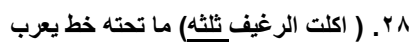

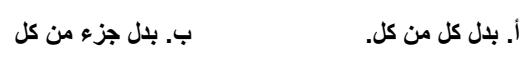

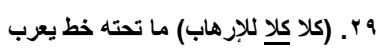

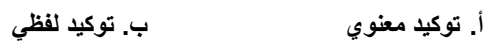

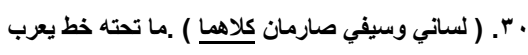

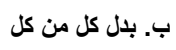

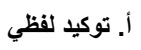

